\title{
Bestrophin-2 mediates bicarbonate transport by goblet cells in mouse colon
}

\author{
Kuai Yu, ${ }^{1}$ Rafael Lujan, ${ }^{2}$ Alan Marmorstein, ${ }^{3}$ Sherif Gabriel, ${ }^{4}$ and H. Criss Hartzell ${ }^{1}$
}

\begin{abstract}
${ }^{1}$ Department of Cell Biology, Emory University School of Medicine, Atlanta, Georgia, USA. ${ }^{2}$ Department of Ciencias Medicas, Facultad de Medicina, Universidad de Castilla-La Mancha, Campus Biosanitario, Albacete, Spain. ${ }^{3}$ Department of Ophthalmology and Vision Science, University of Arizona, Tucson, Arizona, USA. ${ }^{4}$ Department of Pediatrics and the Cystic Fibrosis Center, University of North Carolina, Chapel Hill, North Carolina, USA.
\end{abstract}

\begin{abstract}
Anion transport by the colonic mucosa maintains the hydration and $\mathrm{pH}$ of the colonic lumen, and its disruption causes a variety of diarrheal diseases. Cholinergic agonists raise cytosolic $\mathrm{Ca}^{2+}$ levels and stimulate anion secretion, but the mechanisms underlying this effect remain unclear. Cholinergic stimulation of anion secretion may occur via activation of $\mathrm{Ca}^{2+}$-activated $\mathrm{Cl}^{-}$channels $(\mathrm{CaCCs})$ or an increase in the $\mathrm{Cl}^{-}$driving force through CFTR after activation of $\mathrm{Ca}^{2+}$-dependent $\mathrm{K}^{+}$channels. Here we investigated the role of a candidate CaCC protein, bestrophin-2 (Best2), using Best $2^{-/-}$mice. Cholinergic stimulation of anion current was greatly reduced in Best $2^{-/-}$mice, consistent with our proposed role for Best2 as a CaCC. However, immunostaining revealed Best2 localized to the basolateral membrane of mucin-secreting colonic goblet cells, not the apical membrane of $\mathrm{Cl}^{-}$-secreting enterocytes. In addition, in the absence of $\mathrm{HCO}_{3}^{-}$, cholinergic-activated current was identical in control and Best $2^{-/-}$tissue preparations, which suggests that most of the Best 2 current was carried by $\mathrm{HCO}_{3}^{-}$. These data delineate an alternative model of cholinergic regulation of colonic anion secretion in which goblet cells play a critical role in $\mathrm{HCO}_{3}{ }^{-}$homeostasis. We therefore propose that Best 2 is a $\mathrm{HCO}_{3}{ }^{-}$channel that works in concert with a $\mathrm{Cl}: \mathrm{HCO}_{3}{ }^{-}$exchanger in the apical membrane to affect transcellular $\mathrm{HCO}_{3}{ }^{-}$ transport. Furthermore, previous models implicating CFTR in cholinergic $\mathrm{Cl}^{-}$secretion may be explained by substantial downregulation of Best 2 in $\mathrm{Cftr}^{-/-}$mice.
\end{abstract}

\section{Introduction}

Anion channels and transporters in the gastrointestinal epithelium play essential roles in fluid secretion and absorption and participate in regulating the $\mathrm{pH}$ and ionic composition of the gut luminal contents. The classical view of ion transport in distal colon (see Discussion) holds that there is net absorption of $\mathrm{Na}^{+}, \mathrm{Cl}^{-}$, short-chain fatty acids, and $\mathrm{H}_{2} \mathrm{O}$ and net secretion of $\mathrm{K}^{+}, \mathrm{HCO}_{3}{ }^{-}$, and mucus (1-3). Secretion and absorption are highly specialized topographically: in general, secretion occurs in the crypt, and absorption occurs at the luminal brush border. Secretion is driven by transepithelial $\mathrm{Cl}^{-}$transport that occurs by active basolateral uptake of $\mathrm{Cl}^{-}$by the $\mathrm{Na}^{+} / \mathrm{K}^{+} / 2 \mathrm{Cl}^{-}$cotransporter NKCC1 and subsequent passive efflux via apical (luminal) $\mathrm{Cl}^{-}$channels (3). $\mathrm{Cl}^{-}$transport is accompanied osmotically by $\mathrm{H}_{2} \mathrm{O}$ and electrically by $\mathrm{K}^{+}$and $\mathrm{Na}^{+} . \mathrm{Na}^{+}$and $\mathrm{Cl}^{-}$are then reabsorbed at the brush border surface by coupled $\mathrm{Na}^{+}-\mathrm{H}^{+}$ exchange (i.e., by NHE3) and $\mathrm{Cl}^{-}-\mathrm{HCO}_{3}{ }^{-}$exchange (by SLC26A3) (4). $\mathrm{Na}^{+}$is also reabsorbed by the epithelial $\mathrm{Na}^{+}$channel (ENaC).

The cystic fibrosis transmembrane conductance regulator (CFTR), whose overactivation by bacterial enterotoxins (e.g., cholera toxin) causes secretory diarrhea, and whose dysfunction in certain presentations of cystic fibrosis leads to intestinal blockage, plays a major role in colonic $\mathrm{Cl}^{-}$secretion (5). In addition, anions are secreted simultaneously with mucin in response to agonists that elevate intracellular $\mathrm{Ca}^{2+}$ concentration $\left(\left[\mathrm{Ca}^{2+}\right]\right.$; e.g., refs. 6-8). However, the mechanisms underlying the $\mathrm{Ca}^{2+}$-stimulated anion current are unclear (3). One school of thought favors a role for $\mathrm{Ca}^{2+}$-activated $\mathrm{Cl}^{-}$channels $(6,9)$, whereas another believes that $\mathrm{Ca}^{2+}$ activates $\mathrm{K}_{\mathrm{Ca}} 3.1 \mathrm{~K}^{+}$channels that hyperpolarize the membrane and increase the driving force for anion secretion through CFTR (10-13).

Conflict of interest: The authors have declared that no conflict of interest exists. Citation for this article: J Clin Invest. 2010;120(5):1722-1735. doi:10.1172/JCI41129.
The molecular identity of CaCCs has been elusive, but candidates include members of the bestrophin, CLCA, and TMEM16 families as well as ClC-3 (14-16). Among these candidates, bestrophins have received considerable attention for their roles in a variety of epithelia, including retinal pigment epithelium, airway, and gastrointestinal tract $(14,17)$. Best 1 is expressed in proximal colon in mice and in human colonic epithelial cell lines $(7,8)$. Recently, we generated a mouse in which the first exons of the Best2 gene were replaced with $L a c Z$ and noted that murine Best 2 was strongly expressed in colon (18). In the present study, our initial goal was to test the hypothesis that Best 2 is an apical $\mathrm{CaCC}$ that mediates $\mathrm{Cl}^{-}$secretion. We expected that Best 2 would be expressed on the apical surface of enterocytes in the colonic crypt, but were surprised to find that Best2 was expressed in the basolateral membrane of mucin-secreting goblet cells. We also found that Best 2 was unlikely to participate in colonic $\mathrm{Ca}^{2+}$-activated $\mathrm{Cl}^{-}$secretion, but participated in colonic $\mathrm{HCO}_{3}{ }^{-}$secretion concomitant with mucin secretion. We therefore propose that $\mathrm{HCO}_{3}{ }^{-}$secretion plays a role in mucin expulsion from the crypt into the colonic lumen. Our findings also showed that colonic $\mathrm{Ca}^{2+}$-activated anion secretion was carried largely by $\mathrm{HCO}_{3}{ }^{-}$, and not by $\mathrm{Cl}^{-}$, as previously supposed.

\section{Results}

Lac-Z under control of the Best 2 promoter is expressed in a proximal-distal gradient in the colon

Best $2^{-/-}$mice were constructed with the Lac- $Z$ gene replacing exon 2 and parts of exons 1 and 3 of the Best 2 gene, so that the Lac- $Z$ reporter (with a nuclear localization signal) was under control of the Best 2 promoter (18). The expression of the mouse Best2 gene was evaluated by examining the expression of Lac-Z by X-gal staining. In a 2-month-old mouse, there was a gradient of expression 


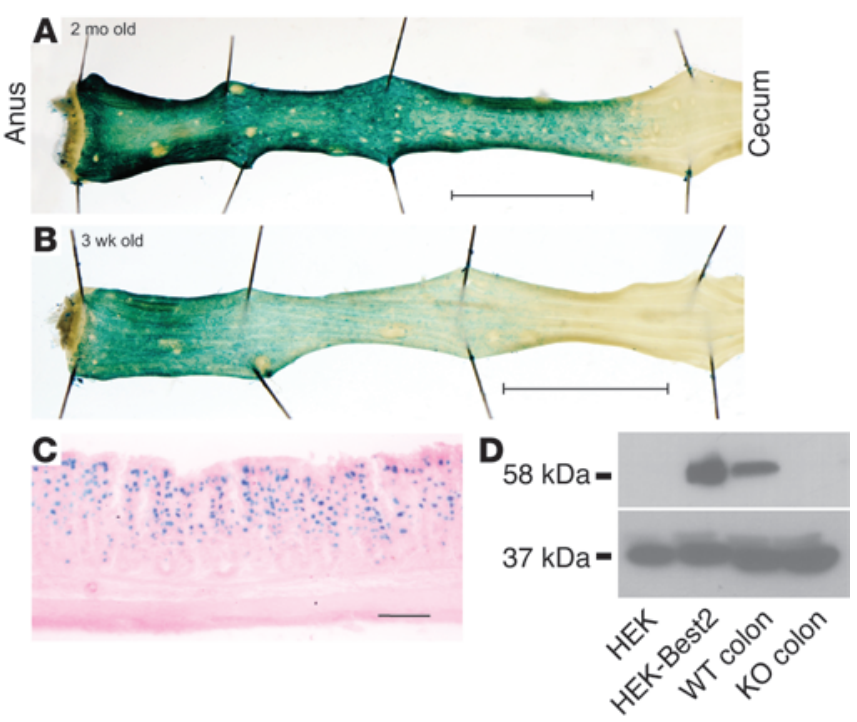

from the cecum, which did not stain at all, to the rectum (Figure 1A). In younger mice, the level of expression was lower, and the staining of the distal colon was reduced compared with the older mice (Figure 1B). Staining localized in the nuclei of cells throughout the crypts (Figure 1C). The Best $2^{-1-}$ mouse was a true Best 2 null, as shown by Western blot: extracts from WT colon or from mouse Best2-transfected HEK cells exhibit a 58-kDa band expected for Best2, whereas extracts from Best2 $2^{-/-}$mice and untransfected HEK cells did not have the Best 2 band (Figure 1D).

\section{Best2 is expressed in a subset of colonic cells in mice and bumans}

To determine which cell types express Best 2 in WT mice, the knockout-verified antibody was used to immunostain sections from a region of colon midway between anus and cecum. A subset of cells exhibited intense Best 2 staining on the basal and lateral membranes (Figure 2A). These cells were located at all levels of the crypt as well as on the luminal brush border surface. At higher magnification (Figure 2, B and C), Best2-positive cells exhibited morphology typical of goblet cells (19). The Best2-positive cells at the tops of the crypts generally had a goblet-like appearance, with an expanded apical end presumably filled with mucin and a cell body that narrows as it approaches the basal lamina. Best2positive cells deeper in the crypts had a more extensive basal surface and tapered apically. The Best2-positive cells did not exhibit apical actin staining with phalloidin (Figure 2, C and D) or with CFTR antibody (Figure 2E), whereas the apical membranes of the Best2-negative enterocytes, both in the crypt and at brush border of the luminal surface, stained intensely with phalloidin and with CFTR antibody. The relative absence of phalloidin staining of the apical membrane is consistent with the fact that goblet cells have fewer actin-containing microvilli than do enterocytes (20).

There are 3 bestrophin paralogs in mice and 4 in humans (Best1Best 3 and BEST1-BEST4, respectively; ref. 14). BEST2 and Best2 are $90 \%$ identical, and thus would be expected to function similarly. Our previous studies show that Best 2 and BEST2 produce similar whole-cell $\mathrm{Ca}^{2+}$-activated anion currents (21). We immunostained human colon sections with specific anti-BEST2 antibodies and found that, like Best2, BEST2 was localized in the basolateral plasma membrane of a subset of colonic cells (Figure 2, G and H).

\section{Figure 1}

Best2 reporter expression in Best2-- mouse colon. (A and B) Lac-Z staining of whole-mount preparations from 2-month-old $(\mathbf{A})$ and 3-week-old (B) Best2-- mice. The colon was dissected from anus to cecum, opened by a longitudinal incision, fixed with $4 \%$ buffered paraformaldehyde, and stained with X-gal. Positive blue staining occurred in a gradient from cecum to most distal colon. Scale bars: $1 \mathrm{~cm}$. (C) Frozen section of distal colon of 2-month-old mouse stained for Lac-Z. Lac-Z-positive nuclei were visible throughout the crypts. Scale bar: $100 \mu \mathrm{m}$. (D) Western blot of Best2 expression. HEK, untransfected HEK cells (negative control); HEK-Best2, HEK cells transfected with Best2 (positive control); WT and $\mathrm{KO}$ colon, an approximatey $1-\mathrm{cm}$ piece of colonic mucosa approximately $1 \mathrm{~cm}$ from the anus of a WT and a Best2 $2^{--}$mouse, respectively. Blot was stained with antibody to Best2 (58 kDa) and antibody to GAPDH as a loading control (37 kDa).

In human tissue, there was a considerable amount of intracellular staining at the basal end of the cells; this staining was punctate and appeared to be localized in vesicles (Figure $2 \mathrm{H}$ ). In mouse colon, there was similar punctate intracellular staining in some cells (Figure 2D), but less than that observed in humans.

\section{Best2-positive cells are goblet cells}

To verify that the Best 2 -positive cells are goblet cells, we costained sections with antibodies against Best 2 and the goblet cell mucin Muc-2. Muc-2 antibody intensely stained the apical portion of cells that were positive for Best2 (Figure 3A). The identity of these cells as goblet cells was confirmed using lectin staining. During biogenesis, mucins are heavily $\mathrm{O}$-glycosylated with $\mathrm{N}$-acetylgalactosamine and galactosyl $(\beta-1,3) \mathrm{N}$-acetylgalactosamine at serine- and threonine-rich tandem repeat domains. These core sugars become heavily sialylated in mature mucin, which can be stained with Sambucus nigra agglutinin (SNA) and Maackia amurensis lectin-II (MAL-II), which recognize sialic acid. The apical region of Best2positive cells stained with both SNA and MAL-II (Figure 3, B and C), confirming the identity of these cells as goblet cells.

Additional evidence that Best 2 is expressed in the plasma membrane of goblet cells was provided by immunoelectron microscopy of goblet cells (Figure 3, D and E). There was no immunostaining in Best2-/- mice (data not shown), whereas in WT mice, immunogold particles were abundant on basal and lateral plasma membranes and in endoplasmic reticulum (Figure 3, F and G).

\section{Best 2 mediates a $\mathrm{Ca}^{2+}$-activated and $\mathrm{HCO}_{3}^{-}$-dependent current in colonic epithelium}

The finding that Best 2 was localized in the basolateral membrane of goblet cells was surprising, because we expected that Best 2 was a CaCC located in the apical membrane of enterocytes involved in $\mathrm{Ca}^{2+}$-stimulated $\mathrm{Cl}^{-}$secretion. To investigate the role of Best 2 in colonic ion transport, we performed shortcircuit current $\left(\mathrm{I}_{\mathrm{sc}}\right)$ analysis on pieces of distal colonic mucosa stripped of smooth muscle mounted in Ussing chambers. Transepithelial currents were recorded with the transepithelial voltage clamped to $0 \mathrm{mV}$. CFTR-mediated currents were activated by elevation of cAMP by forskolin application to the api- 

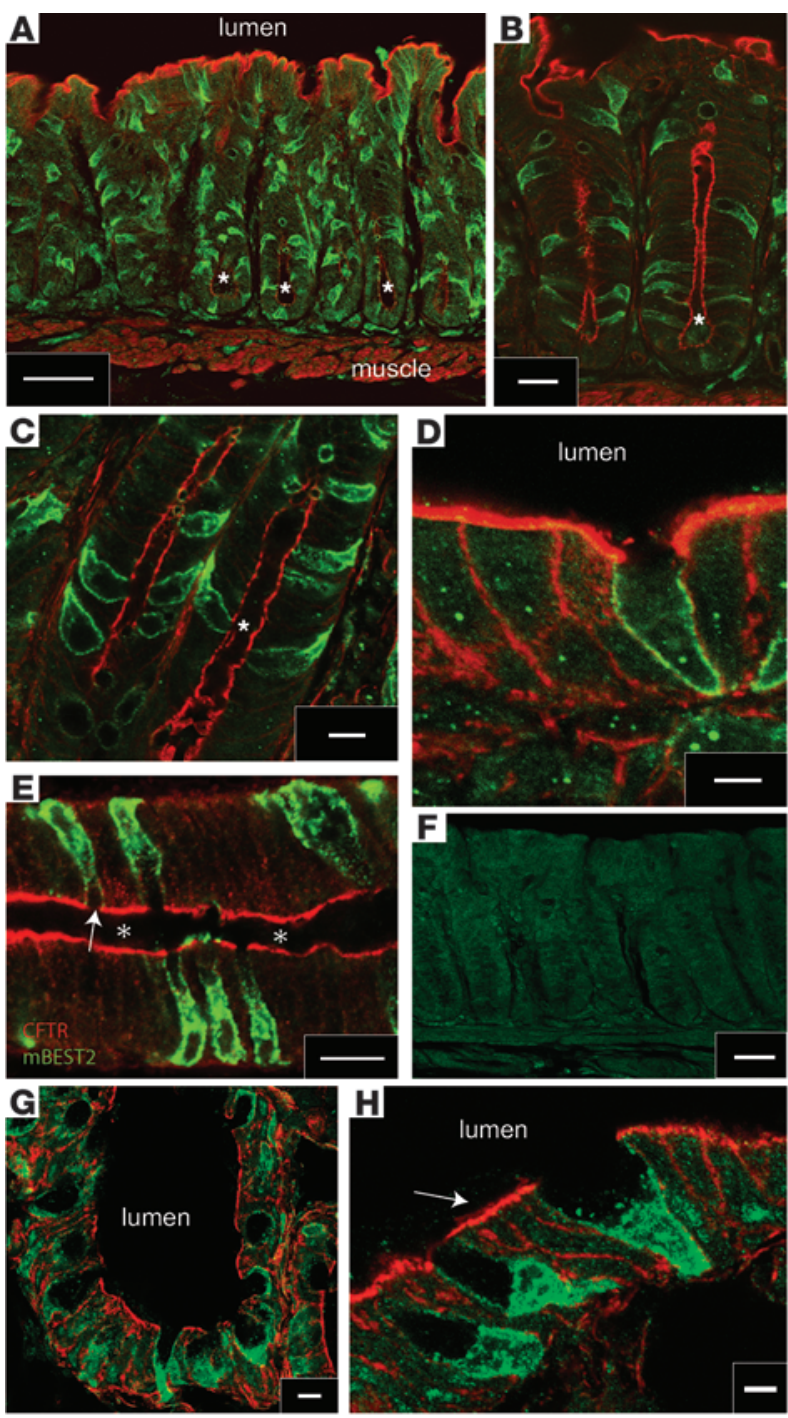

cal (luminal) side, and $\mathrm{Ca}^{2+}$-activated currents were activated by carbachol (CCh) application to activate $\mathrm{G}_{\mathrm{q}}$-coupled muscarinic AChRs on the basal (serosal) side.

Reduced CCh-activated $I_{s c}$ in Best $2^{-/-}$mice. After equilibration of the mucosa, but before application of drugs, the baseline $\mathrm{I}_{\mathrm{SC}}$ recorded in normal Krebs solution was the same in WT $\left(9.8 \pm 0.9 \mu \mathrm{A} \bullet \mathrm{cm}^{2}\right.$, $n=19)$ and Best2 ${ }^{-/-}\left(12.0 \pm 1.3 \mu \mathrm{A}^{\bullet} \mathrm{cm}^{2}, n=13\right)$ mucosa. Amplitudes of forskolin-activated $\Delta \mathrm{I}_{\mathrm{SC}}$ were also the same in $\mathrm{WT}$ and Best $2^{-/-}$mice ( $40.6 \pm 4.0$ and $45.1 \pm 7.1 \mu \mathrm{A} \bullet \mathrm{cm}^{2}$, respectively; Figure 4, A and C), whereas the CCh-activated currents were significantly smaller in Best $2^{-1}$ compared with WT mice ( $26.1 \pm 0.7$ versus $49.4 \pm 4.5 \mu \mathrm{A} \bullet \mathrm{cm}^{2}$; Figure 4, $\mathrm{B}$ and $\mathrm{C})$. The finding that forskolin-activated currents were not affected in the Best $2^{-/-}$mouse is consistent with our observation that CFTR immunostaining was the same in WT and Best2 $2^{--}$mice (data not shown) and showed that CFTR functions normally in Best $2^{-/}$ mice. The decrease in CCh-activated current in the Best2-/- mouse colon is consistent with Best 2 playing a role in this current.

CCh-activated current is composed of multiple components. Our previous studies have shown that Best2 has high permeability to $\mathrm{HCO}_{3}^{-}(21)$. For this reason, we investigated whether the CCh-activated current in the colon was carried by $\mathrm{HCO}_{3}{ }^{-}$. $\mathrm{HCO}_{3}{ }^{-}$was removed from the

\section{Figure 2}

Localization of Best2 in mouse and human colon. Frozen sections of paraformaldehyde-fixed mouse $(\mathbf{A}-\mathbf{F})$ and human $(\mathbf{G}$ and $\mathbf{H})$ distal colon were stained with antibody against Best2 (green) and counterstained with phalloidin to stain actin (A-D, G, and $\mathbf{H}$; red) or antibody against CFTR (E; red). (A) Low-power longitudinal section showing Best2-positive cells scattered throughout the crypt. Asterisks denote the base of the lumen of several crypts. (B-D) Higher-magnification view of crypts (asterisks denote lumen) showing Best2 localization in the basolateral membrane of a subset of cells. (E) CFTR and Best2 antibodies stained different cell types in the crypt. The apical membrane of enterocytes in the crypt (asterisks denote lumen) stained with CFTR antibody, whereas Best2 antibody stained the basolateral membrane of CFTR-negative cells. (F) Specificity of Best2 antibody staining was demonstrated by its absence in Best2 $2^{-/}$mice. ( $\mathbf{G}$ and $\mathbf{H}$ ) Low- and high-power views of BEST2-positive cells in human colon. Arrow indicates brush border membrane. BEST2 staining was evident on basolateral membranes and also in intracellular organelles. Scale bars: $50 \mu \mathrm{m}$ (A and F); $20 \mu \mathrm{m}$ (B); $10 \mu \mathrm{m}$ (C, E, and G); $5 \mu \mathrm{m}$ (D and H).

serosal Krebs solution, and $\mathrm{pH}$ and ionic strength was maintained by addition of Na-HEPES and Na-gluconate. As shown in Figure $4 \mathrm{D}$, the recording was begun in $\mathrm{HCO}_{3}{ }^{-}$-containing solution that also contained $\mathrm{Ba}^{2+}$ and amiloride to block other cation channels. CCh stimulated a current that had a transient peak lasting approximately 1 minute and a prolonged plateau that typically lasted more than 15 minutes. When $\mathrm{HCO}_{3}{ }^{-}$was removed, the plateau current was completely abolished. Restoring $\mathrm{HCO}_{3}{ }^{-}$to the basal chamber restored the current. These results suggest that $\mathrm{CCh}$ stimulates 2 currents, a transient $\mathrm{Cl}^{-}$current and a plateau $\mathrm{HCO}_{3}{ }^{-}$current.

The $\mathrm{HCO}_{3}{ }^{-}$component is mediated by Best2. To test this hypothesis more rigorously and to determine whether the CCh-activated currents were mediated by Best2, we examined the effect of $\mathrm{HCO}_{3}{ }^{-}$ removal on preparations in which basolateral $\mathrm{K}^{+}$channels were blocked by $5 \mathrm{mM} \mathrm{Ba}^{2+}$ and apical $\mathrm{ENaC}$ was blocked with amiloride. As above, under these conditions, CCh activated a current that rose to a peak before decaying to a steady plateau (Figure 4E). The CChactivated current was smaller in Best $2^{-/}$than in WT mucosa (Figure $4 \mathrm{E}) . \mathrm{HCO}_{3}{ }^{-}$removal greatly reduced the CCh-activated current in WT mucosa (Figure 4F). The greatest effect of $\mathrm{HCO}_{3}{ }^{-}$removal was seen on the plateau, with a smaller effect on the initial upstroke, which suggests that the plateau current was carried by $\mathrm{HCO}_{3}{ }^{-}$and that the initial component was carried by other ions, most likely $\mathrm{Cl}^{-}$. Conversely, in Best $2^{-/-}$mucosa, $\mathrm{HCO}_{3}{ }^{-}$removal had a very small, statistically insignificant effect on the CCh-activated current (Figure 4G). These data support the conclusion that a component of the CCh-activated current is carried by $\mathrm{HCO}_{3}{ }^{-}$through Best 2 channels. This conclusion is further supported by the observation that the CCh-activated currents recorded in the absence of $\mathrm{HCO}_{3}{ }^{-}$were identical in WT and Best2 ${ }^{-/-}$mucosa (Figure 4H).

The amplitudes of the $\mathrm{Cl}^{-}$and $\mathrm{HCO}_{3}{ }^{-}$currents are quantified in Figure 4I. $\mathrm{Cl}^{-}$current was defined as the current in $\mathrm{HCO}_{3}{ }^{-}$-free solution with $\mathrm{Ba}^{2+}$ and amiloride. The $\mathrm{HCO}_{3}{ }^{-}$current was defined in 2 different ways. (a) The amplitude of the current in $\mathrm{HCO}_{3}{ }^{-}$-containing Krebs solution at 10 minutes after $\mathrm{CCh}$ addition (i.e., the plateau) was carried largely by $\mathrm{HCO}_{3}{ }^{-}$because the current in $\mathrm{HCO}_{3}{ }^{-}$-free solution was transient and returned to baseline within 10 minutes of CCh application. (b) The difference between the amplitudes of the peak currents (approximately 3 minutes) in normal Krebs (carried by both $\mathrm{Cl}^{-}$and $\mathrm{HCO}_{3}{ }^{-}$) and in $\mathrm{HCO}_{3}{ }^{-}$-free solution (carried largely by $\mathrm{Cl}^{-}$) should represent 

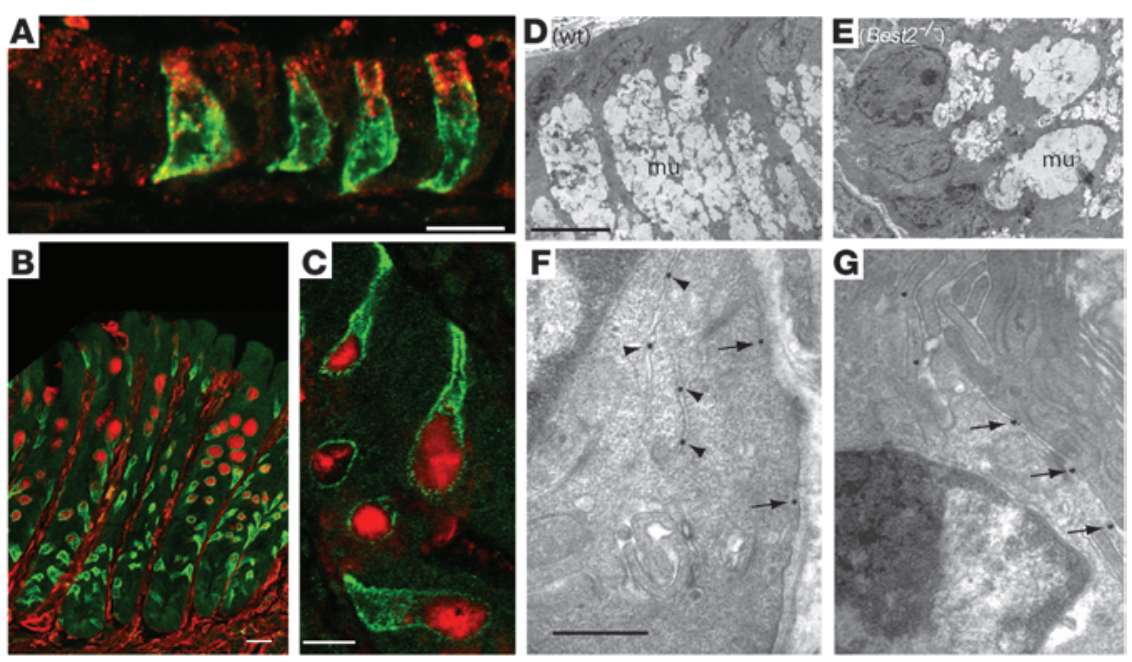

\section{Figure 3}

Best2 is expressed in goblet cells. (A-C) Superimposed confocal images of colon section stained with Best2 (green) and Muc-2 (A; red), SNA (B; red), and MAL-II (C; red). (D-G) Immunoelectron microscopic localization of Best2 in goblet cells of mouse colon. ( $D$ and $\mathbf{E})$ Low-magnification views of goblet cells in WT (D) and Best2-- (E) colon. ( $F$ and $\mathbf{G}$ ) WT colon. Best2 immunogold particles were localized along basolateral plasma membrane (arrows) and rough endoplasmic reticulum (arrowheads) of goblet cells. mu, mucin. Scale bars: $10 \mu \mathrm{m}$ (A and C); $20 \mu \mathrm{m}$ (B); $5 \mu \mathrm{m}$ (D and E); $0.5 \mu \mathrm{m}$ (F and $\mathbf{G})$. the $\mathrm{HCO}_{3}{ }^{-}$current. The $\mathrm{HCO}_{3}{ }^{-}$current amplitude determined by these 2 methods agreed surprisingly well and showed that the $\mathrm{HCO}_{3}{ }^{-}$current in Best $2^{-/-}$mucosa was only $33 \%$ as large as WT.

\section{The $\mathrm{HCO}_{3}^{-}$current is carried mainly by Best 2}

Although $\mathrm{Ca}^{2+}$ clearly activates anion secretion in colon, there is some question as to whether this is mediated by CaCCs or by CFTR. It has been proposed that CFTR channels are opened by elevation of cAMP produced by prostaglandins that are synthesized in response to tissue dissection and manipulation. Under these conditions of basal CFTR activation, $\mathrm{Ca}^{2+}$ may stimulate $\mathrm{Cl}^{-}$flux through these open CFTR channels by activating $\mathrm{Ca}^{2+}$-activated $\mathrm{K}^{+}$channels, hyperpolarizing the membrane, and increasing the driving force for $\mathrm{Cl}^{-}$secretion (see Discussion). To determine whether the $\mathrm{Ca}^{2+}$-stimulated $\mathrm{HCO}_{3}{ }^{-}$current requires CFTR, we performed $\mathrm{I}_{\mathrm{sc}}$ analysis on colons from $\mathrm{Cftr}^{-1}$ mice (homozygous $\left.C f t r^{t m 1 U n c}\right)$. In $\mathrm{Cftr}^{-1-}$ colons, both the total CCh-stimulated current and the $\mathrm{HCO}_{3}{ }^{-}$-dependent component were significantly smaller than in WT colons (Figure 5A). These results are consistent with the suggestion that CFTR may be necessary for the CChstimulated current. However, we wondered whether the apparent dependence of the CCh-stimulated currents on CFTR could be explained by downregulation of Best 2 in the $\mathrm{Cft} \mathrm{fr}^{-1}$ mice. To test this idea, Western blots were performed on samples of the same colons studied in the $\mathrm{I}_{\mathrm{sc}}$ experiments (Figure 5B). Of the samples from $\mathrm{Ctr}^{-1-}$ mice, 2 gave little or no Best 2 signal, whereas the other 2 samples gave weaker signals compared with the control mice. Immunofluorescence microscopy confirmed that the expression of Best 2 was altered in $\mathrm{Cftr}^{-/}$mice. In $\mathrm{Cft}{ }^{-1}$ mice, Best2 staining was weaker when viewed at identical settings and gains. However, more importantly, unlike WT colon, in which Best2 staining was intensely localized in the basolateral plasma membrane (Figure 5, $\mathrm{C}$ and D), in $\mathrm{Cft}^{-1-}$ mice, Best2 staining was not sharply localized to the plasma membrane (Figure 5, E-H). In Cftr-1- mice, Best2 staining was weakly and diffusely distributed in the cytoplasm (compare asterisks in Figure 5, D, F, and H). In addition, in Cftr ${ }^{--}$ mice, there was a considerable amount of Best 2 accumulated in what appeared to be aggregates in the interstitium between crypts and the smooth muscle layer (arrowheads, Figure 5, E-G). These displaced accumulations of Best 2 were never seen in WT tissue. These results suggest that the difference between WT and Cftr ${ }^{-1}$ mice can be explained by an alteration in Best 2 expression in the $\mathrm{Cftr}^{-1}$ mice. These results raise the possibility that CFTR itself may not be required for $\mathrm{Ca}^{2+}$-stimulated $\mathrm{Cl}^{-}$secretion.

We therefore reexamined other evidence supporting the idea that $\mathrm{Ca}^{2+}$ stimulates $\mathrm{Cl}^{-}$secretion through CFTR. Evidence that the $\mathrm{Ca}^{2+}$-activated $\mathrm{Cl}^{-}$current is carried by CFTR has been supported by the observation that the response to $\mathrm{CCh}$ is blocked when prostaglandin synthesis is inhibited by indomethacin (10, 11). Prostaglandins generated during tissue manipulation are believed to be responsible for a basal level of CFTR activation, but we considered an alternative possibility: namely, that indomethacin may directly block currents carried by Best 2 . In HEK-293 cells expressing Best2, we found that indomethacin at concentrations typically used by others in Ussing chamber experiments $(10 \mu \mathrm{M})$ blocked Best 2 currents by approximately $80 \%$ (Figure 6, B and E). We also measured the effect of indomethacin on currents generated by another candidate $\mathrm{CaCC}$ channel, anoctamin 1 (Ano1; see below). Indomethacin did not block Ano1 currents at the same concentration (Figure 6, D and E).

There is considerable evidence that $\mathrm{CCh}$ activates $\mathrm{Ca}^{2+}$-activated $\mathrm{K}^{+}$channels (e.g., $\mathrm{K}_{\mathrm{Ca}} 3.1$, SK4, and IK1) reported to be necessary for CCh-stimulated $\mathrm{Cl}^{-}$secretion (e.g., ref. 12). Activation of these channels could result in increased $\mathrm{Cl}^{-}$efflux through CFTR (if CFTR channels were open). One line of evidence suggesting that $\mathrm{K}_{\mathrm{Ca}} 3.1$ channels are necessary for $\mathrm{Ca}^{2+}$-activated $\mathrm{Cl}^{-}$secretion is the observation that clotrimazole, a blocker of $\mathrm{K}_{\mathrm{Ca}} 3.1$ channels, blocks the CCh-stimulated $\mathrm{Cl}^{-}$current (12). We found that clotrimazole also blocked Best 2 channels by approximately $80 \%$ and Ano 1 channels expressed in HEK-293 cells by 70\% (Figure 6, A and C). The block of Best 2 channels is more slowly reversible than the block of Ano1 channels. Taken together, these data show that CFTR is unlikely to contribute significantly to the CCh-stimulated $\mathrm{HCO}_{3}{ }^{-}$ current in mouse colon.

\section{$\mathrm{Ca}^{2+}$-activated anion channels in isolated colonocytes}

$\mathrm{CCh}$ activates a fast $\mathrm{Cl}^{-}$current in addition to the slow $\mathrm{HCO}_{3}{ }^{-}$current carried by Best 2 . To gain additional insight into the channels that carry the $\mathrm{Cl}^{-}$component, we performed whole-cell patch clamp recording on freshly isolated cells isolated from distal colon. These isolated colonocytes are expected to be a mixture of goblet cells and enterocytes. Cells patch-clamped with less than $20 \mathrm{nM}$ free $\left[\mathrm{Ca}^{2+}\right]_{\mathrm{i}}$ in 

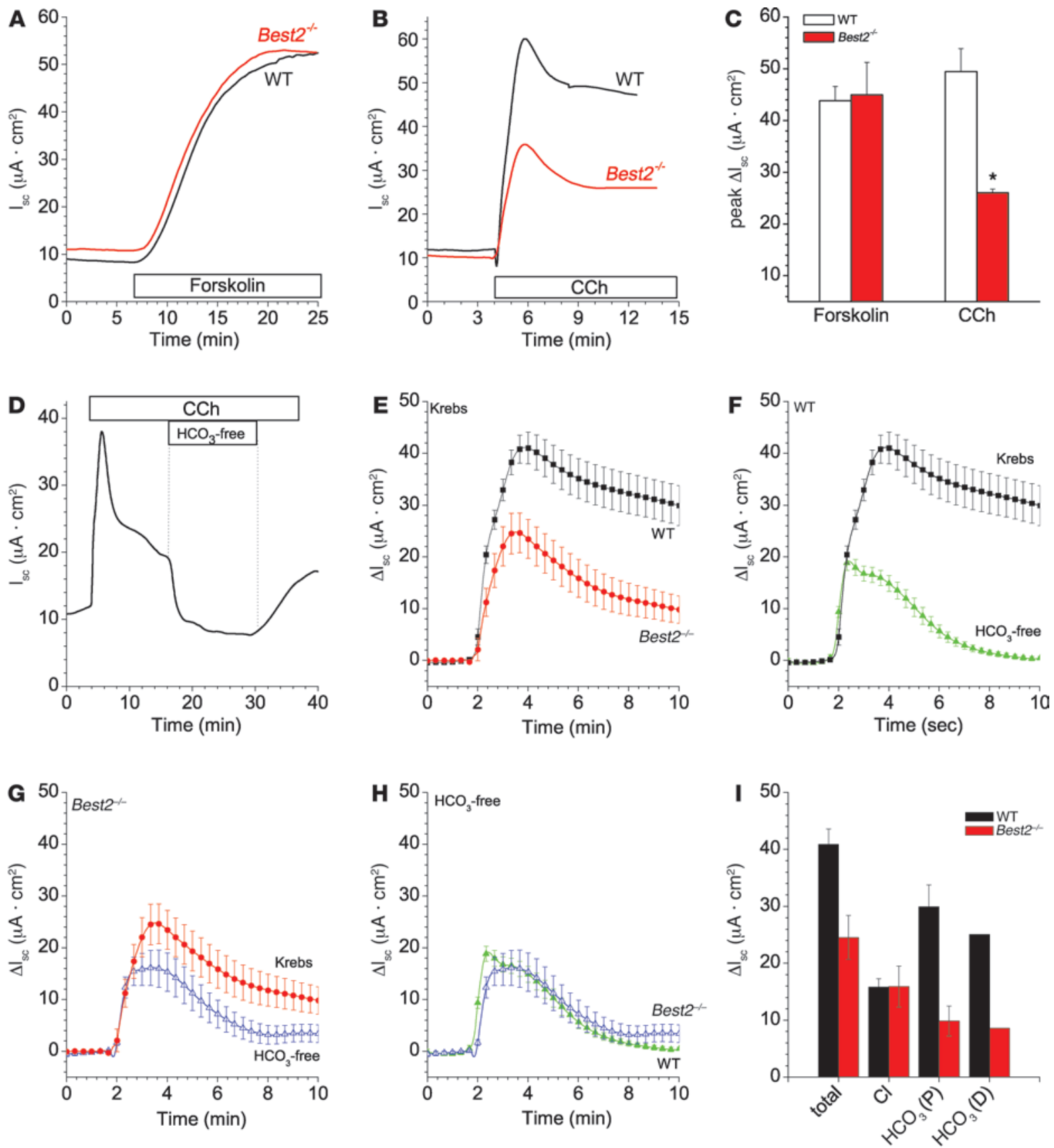

Figure 4

$\mathrm{I}_{\mathrm{sc}}$ in WT and Best2--- distal colonic mucosa. Upward currents represent anion movement from serosa to lumen. (A and B) Representative $\mathrm{I}_{\mathrm{sc}}$ in response to $10 \mu \mathrm{M}$ forskolin (A) and $1 \mathrm{mM}$ CCh (B) in WT and Best2-/- mice. (C) Peak $\mathrm{sc}_{\mathrm{sc}}$ amplitudes to forskolin or CCh in WT and Best2 ${ }^{-/-}$mice $(n=6-10)$. ${ }^{*} P<0.05$ versus WT, Student's $t$ test. (D-I) I $\mathrm{sc}_{\mathrm{sc}}$ mediated by $\mathrm{Cl}^{-}$and $\mathrm{HCO}_{3}{ }^{-}$. Solutions contained $5 \mathrm{mM} \mathrm{Ba}^{2+}$ and $0.1 \mathrm{mM}$ amiloride. (D) Effect of $\mathrm{HCO}_{3}-$ removal on CCh-stimulated current in WT mucosa. In normal Krebs solution, CCh induced a rapid peak followed by plateau. $\mathrm{HCO}_{3}{ }^{-}$removal inhibited the plateau. (E) Average $\mathrm{I}_{\mathrm{sc}}$ in WT and Best $2^{-1-}$ mice. CCh was added at 2 minutes. (F and $\left.\mathbf{G}\right) \mathrm{CCh}$-stimulated current in WT (F) and Best2 $2^{-/-}(\mathbf{G})$ mucosa in normal Krebs and $\mathrm{HCO}_{3}^{-}$-free solutions. (H) Replot of data in $\mathbf{F}$ and $\mathbf{G}$ comparing $\mathrm{Cl}^{-}$currents in $\mathrm{HCO}_{3}{ }^{-}$-free Krebs in WT and Best2-- mice. (I) Comparison of $\mathrm{Cl}^{-}$and $\mathrm{HCO}_{3}{ }^{-}$currents stimulated by CCh in WT and Best2--- mucosa. Total, current in normal Krebs; $\mathrm{Cl}, \mathrm{Cl}^{-}$current in $\mathrm{HCO}_{3}{ }^{-}$-free solution; $\mathrm{HCO}_{3}(\mathrm{P})$, amplitude of plateau current 8 minutes after $\mathrm{CCh}$ application in normal $\mathrm{Krebs} \mathrm{HCO}_{3}(\mathrm{D})$, difference between currents at peak (about 1-2 minutes after CCh application) in normal Krebs and in $\mathrm{HCO}_{3}^{-}$-free solution. $n=10$ per data point.

the pipette had very small currents (Figure $7, \mathrm{~A}$ and $\mathrm{D}$ ), but large $\mathrm{Cl}^{-}$ currents were recorded with approximately $1 \mu \mathrm{M}$ free $\left[\mathrm{Ca}^{2+}\right]_{\mathrm{i}}$ (Figure 7 , B-D). We studied a total of 25 WT cells and 30 Best $2^{-/-}$cells with high $\left[\mathrm{Ca}^{2+}\right]_{\mathrm{i}}$ solution, and observed 2 different current waveforms in dif- ferent cells. One linear and time-independent waveform (Figure 7C) was observed in $36 \%$ of WT cells and $43 \%$ of Best $2^{-/-}$cells, although the current was much smaller in Best $2^{-/-}$cells. The percentage of cells with this current waveform roughly corresponded to the proportion 


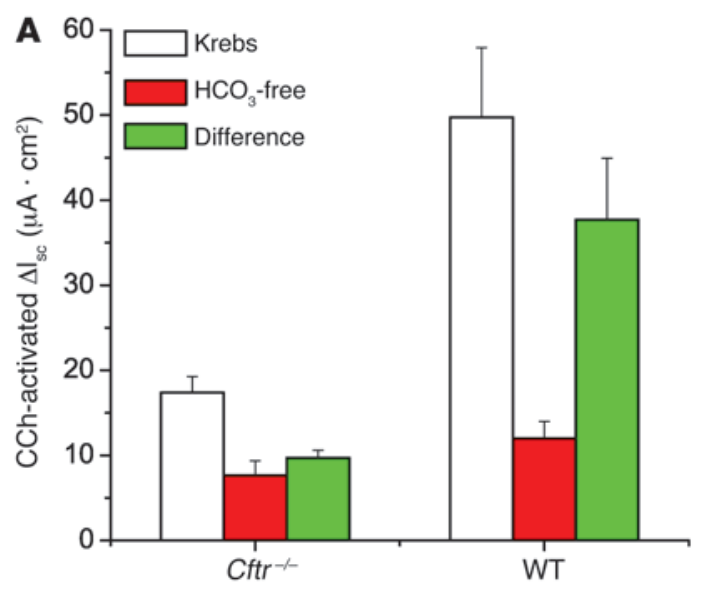

B
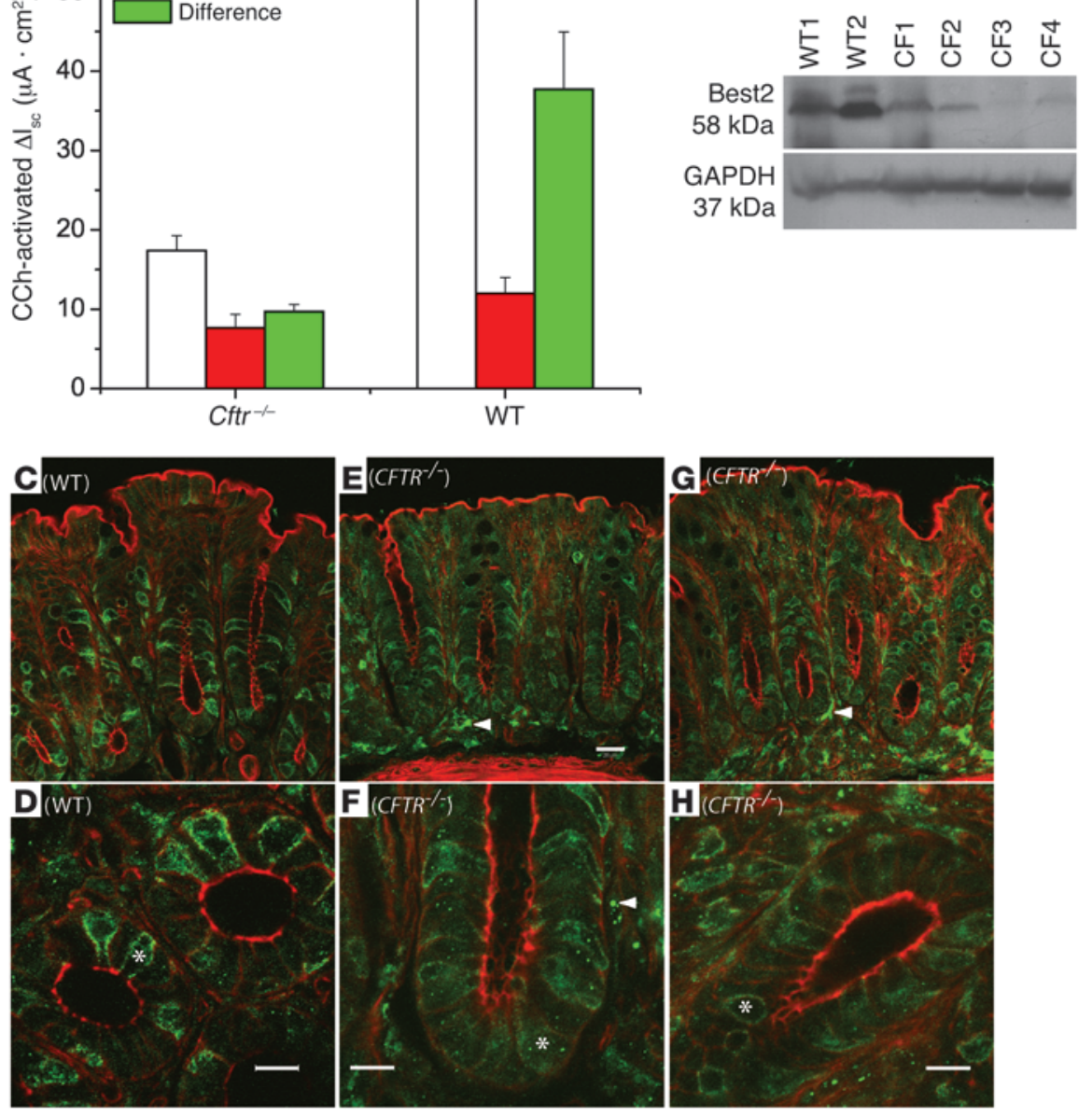

\section{Figure 5}

Best2 expression in colon from $\mathrm{Cftr}^{-1-}$ mice. (A) $\mathrm{I}_{\mathrm{sc}}$ from $\mathrm{Cftr}^{-1-}$ and WT mice, recorded as in Figure 4. Shown are results with normal Krebs and $\mathrm{HCO}_{3}{ }^{-}$-free solutions as well as the difference between them. $n=5$ mucosal samples from 2 WT mice; $n=9$ mucosal samples from $4 \mathrm{Cftr}^{-1-}$ mice. $P<0.01$, all $\mathrm{Cftr}^{-1}$ versus all respective WT values. (B) Western blot of Best2 expression in WT (WT1 and WT2) and $\mathrm{Cftr}^{-1-}$ (CF1-CF4) colon samples. Samples were the same ones used for $I_{\text {sc }}$ measurements in A. Blots were stained with Best2 (58 kDa) and GAPDH (37 kDa) antibodies. (C-H) Immunofluorescence of WT (C and D) and $\mathrm{Cftr}^{-1}(\mathbf{E}-\mathrm{H})$ colon samples. Samples are adjacent tissue from the same colons used for $I_{s c}$ measurements in A. Arrowheads in $\mathbf{E}$ and $\mathbf{F}$ indicate interstitial accumulation of Best2 staining; asterisks in $\mathbf{D}, \mathbf{F}$, and $\mathbf{H}$ are shown for comparison of Best2 staining in the cytoplasm for comparison. Scale bars: $20 \mu \mathrm{m}$ (C, E, and G); $10 \mu \mathrm{m}$ (D, F, and H). of goblet cells existing in this region of the colon (e.g., Figure 2A). We believe that the cells with linear currents are goblet cells, because the linear current resembled that induced by Best 2 expressed in HEK cells (Figure 7, compare $\mathrm{C}$ and $\mathrm{H}$ ), and its amplitude was reduced $60 \%$ in Best2 $2^{-/}$cells (Figure 7F). The presence of a small linear current in the knockouts may be explained by an uncompensated leak current in some cells. The other waveform resembled a classical outwardly rectifying, time-dependent CaCC current (Figure 7B). The amplitudes of the outwardly rectifying currents were statistically the same in WT and Best2 ${ }^{-/}$mice (Figure 7E). The outwardly rectifying current was most likely mediated by the newly discovered Ano1 (TMEM16A) channel (22-24), because it resembled the currents induced by Ano1 expression in HEK cells (Figure 7, compare B and G). Transcripts for Ano1, Ano6, Ano7, and Ano10 were expressed in colonic mucosa (Figure 8A). Western blots showed that HEK293 cells transfected with Ano1 had a faint band at the expected mass of $110 \mathrm{kDa}$ and a larger, diffuse band representing glycosylated protein (Figure 8B). A similar diffuse band was observed in extracts from distal colon. Staining frozen sections with the Ano1 antibody showed intense staining in interstitial cells of Cajal, as previously reported by Gomez-Pinilla et al. (25), as well as in cells of the brush border membrane (Figure 8C).

To determine whether Ano1 contributes to $\mathrm{HCO}_{3}{ }^{-}$permeability, we measured the relative $\mathrm{HCO}_{3}{ }^{-}$permeability and conductance of the Ano1 channel (Figure 7I). Ano1 had low permeability to
$\mathrm{HCO}_{3}{ }^{-}$compared with Best2 $\left(\mathrm{HCO}_{3}{ }^{-} / \mathrm{Cl}^{-}\right.$ratio, 0.3 versus 0.7$)$. These data support the conclusion that Ano1 is responsible for a Ca${ }^{2+}$-activated $\mathrm{Cl}^{-}$current in colon, whereas Best 2 is responsible for a $\mathrm{Ca}^{2+}$-activated $\mathrm{HCO}_{3}{ }^{-}$current.

\section{Phenotype of Best $2^{-/-}$mice}

If Best 2 plays a role in colon homeostasis, one would expect a phenotypic defect in colon function in the Best $2^{-/-}$mice. Best $2^{-/-}$mice, especially females, gained weight slightly less quickly than did WT mice with the same genetic background. The difference was small, but statistically significant by factorial ANOVA, for both males $(P=0.003$; Figure 9A) and females $(P<0.001$; Figure 9B). Histological examination revealed that colons from Best $2^{-/-}$mice exhibited an elevated level of inflammation, as indicated by the presence of eosinophils and neutrophils and a significantly elevated myeloperoxidase (MPO) level (Figure 9, D, E, and G). Otherwise, the gross appearance and histology of the colons from Best $2^{-/-}$mice, including the number of goblet cells as determined by lectin immunofluorescence, was not obviously different from that of WT mice.

Because the effect of disruption of Best 2 might not be evident in animals raised in the ideal, relatively aseptic conditions of the animal quarters, we induced experimental colitis by feeding the animals dextran sulfate sodium (DSS; ref. 26), and found that Best2 ${ }^{-/-}$mice were more sensitive to DSS treatment than were 

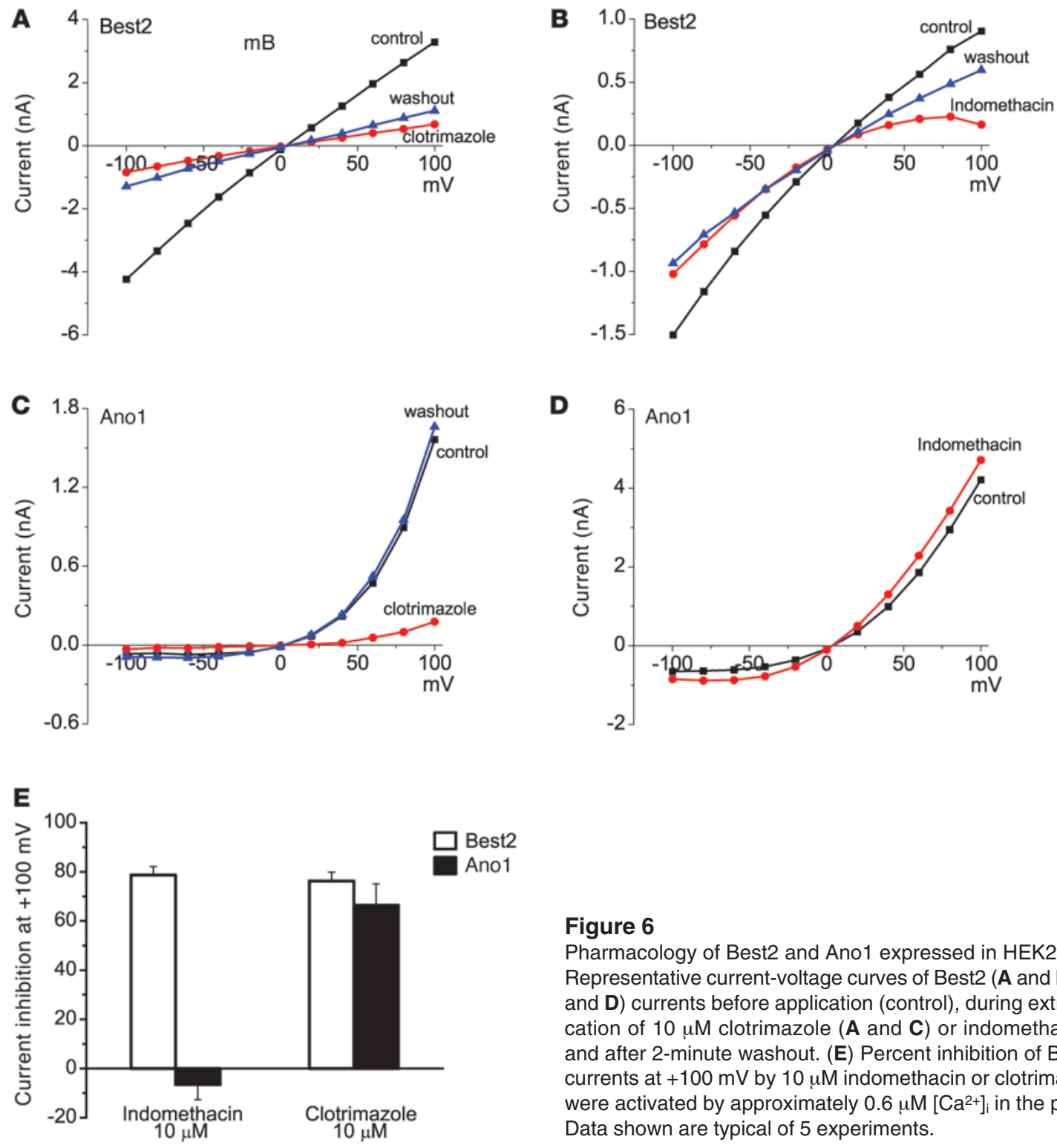

Figure 6

Pharmacology of Best2 and Ano1 expressed in HEK293 cells. (A-D) Representative current-voltage curves of Best2 (A and B) and Ano1 (C and D) currents before application (control), during extracellular application of $10 \mu \mathrm{M}$ clotrimazole (A and $\mathbf{C}$ ) or indomethacin (B and $\mathbf{D}$ ), and after 2-minute washout. (E) Percent inhibition of Best2 and Ano1 currents at $+100 \mathrm{mV}$ by $10 \mu \mathrm{M}$ indomethacin or clotrimazole. Currents were activated by approximately $0.6 \mu \mathrm{M}\left[\mathrm{Ca}^{2+}\right]_{i}$ in the pipette solution. Data shown are typical of 5 experiments.

WT mice. Best2 $2^{-/-}$mice lost an average of $10.2 \% \pm 3.4 \%$ of their body weights after treatment with DSS, whereas WT mice lost only $3.7 \% \pm 1.2 \%$ (Figure 9F). At the end of the 6 -day DSS treatment period, MPO was substantially elevated in both groups, although the responses of the 2 groups were not significantly different (Figure 9G). Best $2^{-/-}$mice recovered from DSS treatment less quickly than did WT mice: 5 days after DSS treatment, the Best $2^{-/-}$mice had not regained the body weight they had lost, whereas WT mice were approximately $5 \%$ above their starting weight (Figure 9F). Furthermore, at 18 days after DSS treatment was ended, MPO levels in WT mice had returned to control levels, whereas MPO levels in Best2-/- mice remained 4.8-fold higher than the WT control level (Figure 9G).

Because there was such a large difference between groups in their recovery from DSS treatment, we examined the distribution of goblet cells 1 week after cessation of DSS treatment. In WT animals, there was tremendous hyperplasia of Best2-positive goblet cells (Figure 9H). In some sections, it appeared that

nearly every cell in the crypt was positive for Best 2 . In colons prepared in parallel, control sections had less than 15 Best2positive cells per crypt (range, $8-15$ cells), whereas DSS-recovery sections had greater than 25 positive cells (range, $25-40$ cells). In addition, many of the cells at the brush border surface were also Best2-positive (approximately 10 cells per 100- $\mu$ m colon length), whereas in control colons, surface Best2-positive cells were seen infrequently (less than 1 cell per $100-\mu \mathrm{m}$ colon length). Because we cannot use Best 2 staining to compare WT and Best $2^{-/-}$goblet cell hyperplasia, we used peanut agglutinin (PNA), which recognizes the O-linked core galactosyl $(\beta-1,3) \mathrm{N}$-acetylgalactosamine to label mucin. Virtually every Best2-positive cell in the WT colon recovering from DSS treatment also stained with PNA (Figure 9H). In contrast, colon from Best $2^{-/-}$mice recovering from DSS treatment exhibited little PNA staining (Figure 9I). These data clearly demonstrate that either mucin biogenesis or goblet cell differentiation is abnormal in Best $2^{-/-}$colon when the animal is subjected to stress. 

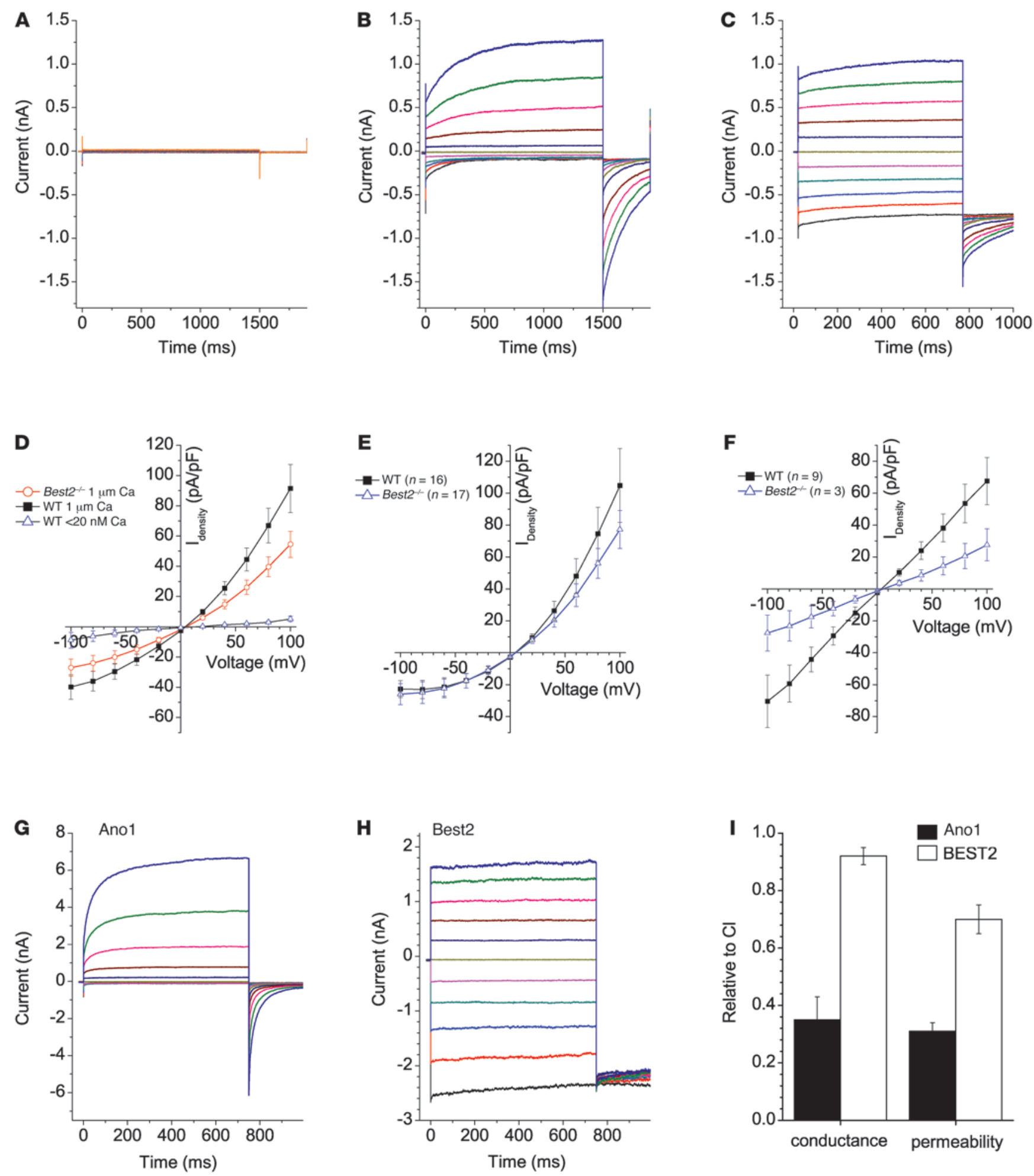

\section{Figure 7}

Anion currents recorded from freshly isolated colonocytes and transfected HEK293 cells. (A-C) Sample traces from isolated colonocytes with less than $20 \mathrm{nM}$ free $\left[\mathrm{Ca}^{2+}\right]_{\mathrm{i}}(\mathbf{A})$ or $1 \mu \mathrm{M}\left[\mathrm{Ca}^{2+}\right]_{\mathrm{i}}(\mathbf{B}$ and $\mathbf{C})$, showing different waveforms observed in different cells. (D) Current-voltage relationships for WT colonocytes with less than $20 \mathrm{nM}$ free $\left[\mathrm{Ca}^{2+}\right]_{i}$ as well as WT and Best2-l- colonocytes with $1 \mu \mathrm{M}$ free $\left[\mathrm{Ca}^{2+}\right]_{\mathrm{i}}$. $(\mathrm{E}) \mathrm{Comparison}^{-}$of current-voltage relationships of outwardly rectifying currents as in B from WT and Best2-l- mice with $1 \mu \mathrm{M}$ free $\left[\mathrm{Ca}^{2+}\right]_{\mathrm{i}}$. (F) Comparison of current-voltage relationships of linear currents as in $\mathbf{C}$ from WT and Best2- mice with $1 \mu \mathrm{M}$ free $\left[\mathrm{Ca}^{2+}\right]_{\mathrm{i} .}$ (G) Representative currents in HEK cells transfected with Ano1 cDNA with $1 \mu \mathrm{M}$ free $\left[\mathrm{Ca}^{2+}\right]$ i. (H) Representative currents in HEK cells transfected with Best2 cDNA with $1 \mu \mathrm{M}$ free $\left[\mathrm{Ca}{ }^{2+}\right]$ i. (I) Permeability and conductance, relative to $\mathrm{Cl}$, of Ano1 and Best2 currents. 

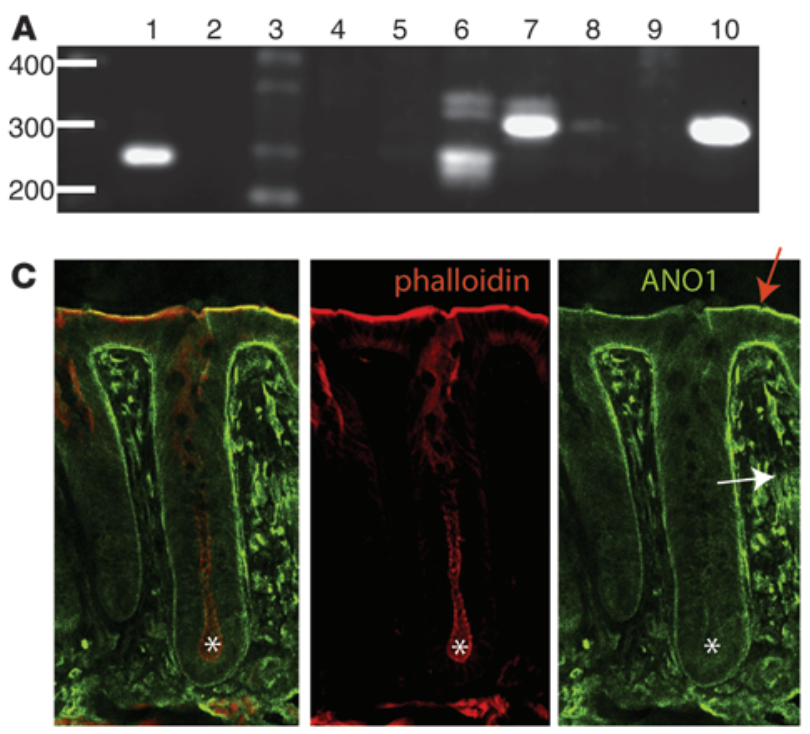

\section{Discussion}

These studies provide a number of insights. First, the function of bestrophins has been enigmatic since they were proposed to be $\mathrm{Cl}^{-}$channels in $2002(14,16)$. For the first time to our knowledge, our results demonstrate a role of bestrophins in $\mathrm{HCO}_{3}{ }^{-}$transport and open a window into the physiology of this family of channels. Second, our results provide insights into the poorly understood ion transport properties of colonic goblet cells, which are of fundamental importance in colonic physiology. Finally, we provide perspective on the regulation of colonic anion transport by proposing what we believe to be a novel mechanism for the role of cholinergic agonists.

Hypothesis. The data presented here show that Best2 is expressed on the basolateral membrane of goblet cells and that disruption of Best 2 causes a decrease in a CCh-activated $\mathrm{HCO}_{3}{ }^{-}$-dependent transepithelial current. Because Best 2 is highly permeant to $\mathrm{HCO}_{3}{ }^{-}$when expressed heterologously in $\mathrm{HEK}$ cells (21), and $\mathrm{HCO}_{3}{ }^{-}$-dependent transport was reduced in the Best $2^{-/-}$mouse, we conclude that Best2 is a channel that mediates vectorial transepithelial secretion of $\mathrm{HCO}_{3}{ }^{-}$. However, we should point out that we have not measured $\mathrm{HCO}_{3}{ }^{-}$secretion directly. Given the fact that Best 2 may have other regulatory functions (14), it is possible that the $\mathrm{HCO}_{3}{ }^{-}$dependence of the transepithelial current might be caused by an effect of $\mathrm{HCO}_{3}{ }^{-}$on some other function of Best2. Also, it is important to note that Best 2 is not only found on the plasma membrane, but also in intracellular organelles (Figure 2). Best2 may, therefore, have intracellular functions. Recently, it has been reported that Best 1 is an ER protein that regulates $\mathrm{ER} \mathrm{Ca}^{2+}$ transport (27).

How could passive movement of $\mathrm{HCO}_{3}{ }^{-}$across the basolateral membrane of the goblet cell mediate transepithelial $\mathrm{HCO}_{3}{ }^{-}$transport? Our hypothesis is summarized in Figure 10B. In contrast to the classical view of ion transport in distal colon (Figure 10A), we propose that $\mathrm{HCO}_{3}{ }^{-}$moves passively across the basolateral membrane and is then transported into the colonic lumen by an apical $\mathrm{Cl}^{-}: \mathrm{HCO}_{3}^{-}$exchanger. Whether this is thermodynamically feasible depends upon some unknown variables, notably the potentials across the basolateral and apical membranes of goblet cells. However, we can calculate the range of membrane potentials that would permit such a mechanism to operate. We assume that serosal $\mathrm{HCO}_{3}{ }^{-}$is similar to plasma (approximately $25 \mathrm{mM}$ ). $\left[\mathrm{HCO}_{3}{ }^{-}\right]_{\mathrm{i}}$

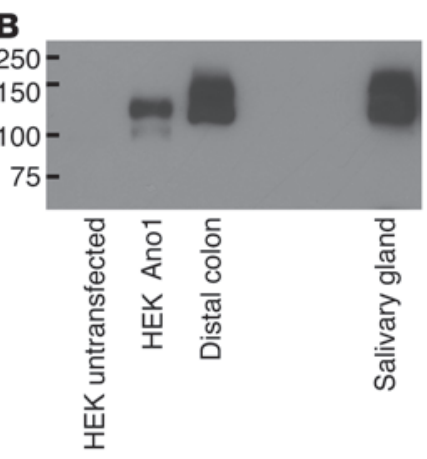

Figure 8

Expression of anoctamins in colon. (A) RT-PCR of Ano1-Ano10 from mouse distal colonic epithelium. (B) Western blot of Ano1 expression in untransfected HEK cells, HEK cells transfected with Ano1 cDNA, distal colon, and salivary gland. (C) Confocal microscopy of Ano1 expression in colon. Brush border lumen is at the top. Asterisks mark the bottom of the crypt. Interstitial cells and the brush border are denoted by white and red arrows, respectively. Shown are Ano1 and phallodin alone as well as the overlay (left). levels have been experimentally determined to be $8-15 \mathrm{mM}$ in colonocytes at normal arterial $\mathrm{pCO}_{2}$ (28). If these values also apply to goblet cells, the Nernst equilibrium potential for $\mathrm{HCO}_{3}^{-}$ across the basolateral membrane would range from $-30 \mathrm{mV}$ at $8 \mathrm{mM}\left[\mathrm{HCO}_{3}{ }^{-}\right]_{\mathrm{i}}$ to $-13 \mathrm{mV}$ at $15 \mathrm{mM}\left[\mathrm{HCO}_{3}{ }^{-}\right]_{\mathrm{i}}$. The transepithelial potential (TEP) of distal colon in our studies is typically -1 to $-2 \mathrm{mV}$ (apical negative relative to serosal; see also refs. 2,12 ). This value is less than other epithelia, including the small intestine, partly because the colonic epithelium is more leaky; moreover, the high proportion of goblet cells in distal colon may contribute to the lower TEP. In any case, such a small TEP would dictate that the apical membrane potential must be close to the basolateral membrane potential. If secretion of $\mathrm{HCO}_{3}{ }^{-}$into the colonic lumen is powered by an apical $\mathrm{Cl}^{-}: \mathrm{HCO}_{3}{ }^{-}$exchanger, the equilibrium luminal $\left[\mathrm{HCO}_{3}{ }^{-}\right]$concentration would be calculated as follows: $\ln \left(\left[\mathrm{HCO}_{3}\right]_{\mathrm{i}} /\left[\mathrm{HCO}_{3}\right]_{\mathrm{o}}\right)^{\mathrm{m}}=\ln \left([\mathrm{Cl}]_{\mathrm{i}} /[\mathrm{Cl}]_{\mathrm{o}}\right)^{\mathrm{n}}+\left(\left[n \times z_{\mathrm{Cl}}\right]-\left[m \times z_{\mathrm{HCO} 3}\right]\right)$ $\times F V_{m} / R T$, in which $n$ and $m$ represent the stoichiometry of the $\mathrm{Cl}^{-}: \mathrm{HCO}_{3}$ exchanger, $z$ is the valence (i.e., -1$), V_{m}$ is the membrane potential, and $F, R$, and $T$ have their usual thermodynamic meanings (29). With total [anion] of $160 \mathrm{mM},\left[\mathrm{HCO}_{3}\right]_{\mathrm{i}}$ of $10 \mathrm{mM}$, apical $V_{m}$ of $-25 \mathrm{mV}$, and $[\mathrm{Cl}]_{\mathrm{i}}$ of $40 \mathrm{mM}$, the luminal $\left[\mathrm{HCO}_{3}^{-}\right]$would be predicted to be $29-37 \mathrm{mM}$, depending on the $\mathrm{Cl}: \mathrm{HCO}_{3}$ stoichiometry of the exchanger (29). Thus, a basolateral $\mathrm{HCO}_{3}{ }^{-}$channel and an apical $\mathrm{Cl}: \mathrm{HCO}_{3}$ exchanger could theoretically drive secretion of significant amounts of $\mathrm{HCO}_{3}{ }^{-}$. $\mathrm{HCO}_{3}{ }^{-}$could be secreted even if the goblet cell basolateral membrane potential were more negative than $-30 \mathrm{mV}$; however, a more negative membrane potential would result in an equilibrium $\left[\mathrm{HCO}_{3}^{-}\right]_{i}$ lower than $8 \mathrm{mM}$, which would likely produce an unphysiologically acidic intracellular $\mathrm{pH}$. Whether these calculations reflect reality is limited by the little data available on the membrane properties of colonic goblet cells; we do not know what additional conductances are present in the apical and basolateral membranes.

$\mathrm{HCO}_{3}{ }^{-}$is thought to be important in secretion of mucins, which play a key role in the innate immune system of the gut. Mucins are stored in intracellular granules in a compacted form with high concentrations of $\mathrm{Ca}^{2+}$ and protons (30) that screen the negative charges in the highly polyanionic mucins. When mucins are exocytosed, they rapidly expand in volume by 1,000 -fold (31). This 

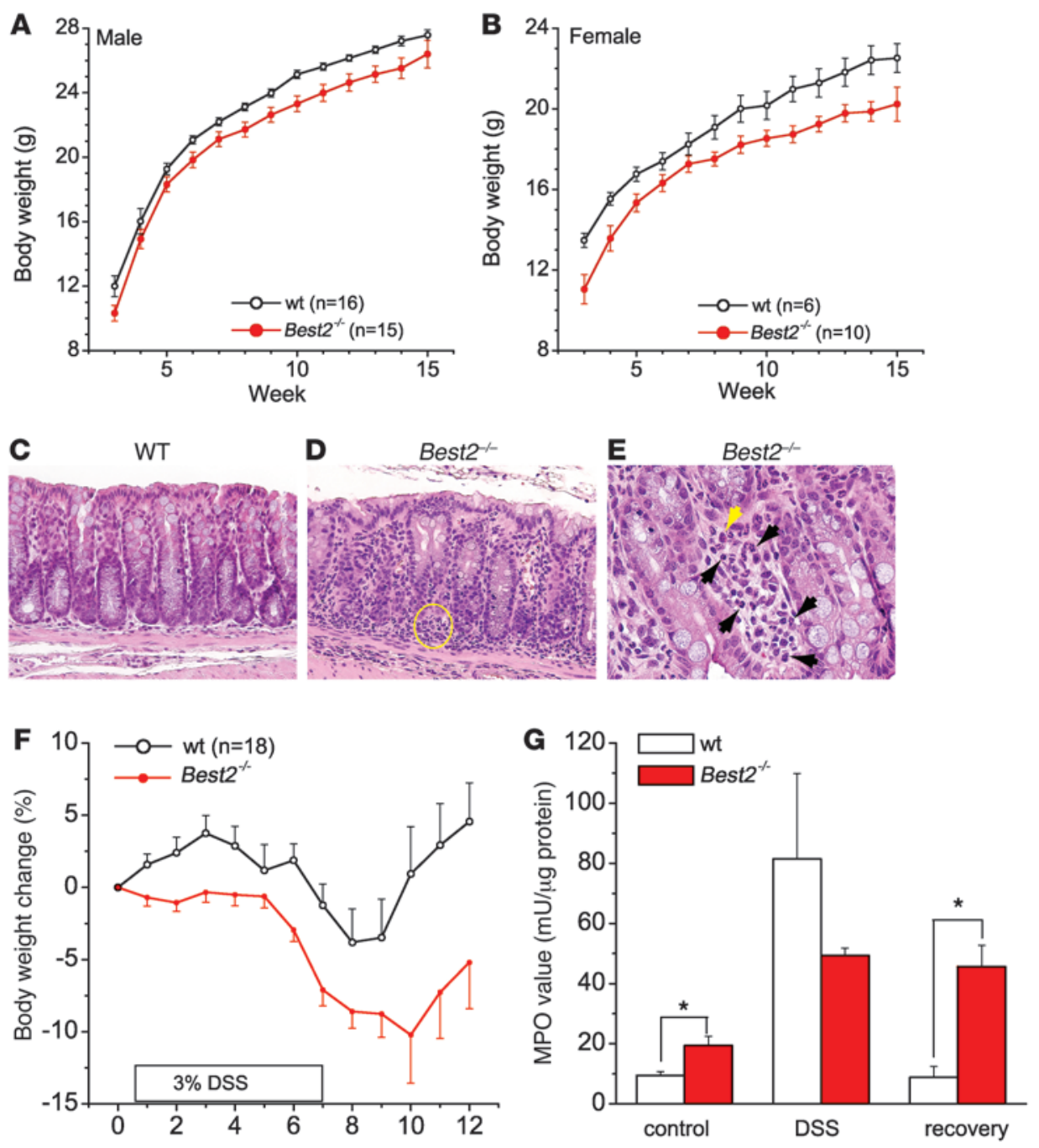

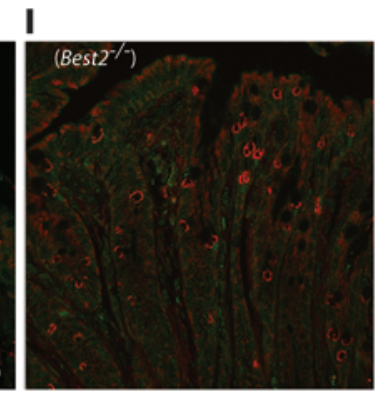

expansion is thought to be driven in part by electrostatic repulsion of negative charges that are unmasked during exocytosis. It has been suggested that $\mathrm{HCO}_{3}{ }^{-}$plays a critical role in unmasking these charges by raising the $\mathrm{pH}$ and sequestering $\mathrm{Ca}^{2+}(32)$.

Mechanisms of anion secretion in distal colon. Activation of CFTR, expressed in the apical membrane of enterocytes in the crypts (Figure 2E), is responsible for $\mathrm{Cl}^{-}$secretion activated by agonists that elevate cAMP (5). Agonists that elevate $\left[\mathrm{Ca}^{2+}\right]_{\mathrm{i}}$ also stimulate anion secretion (e.g., refs. 6-8), but the mechanisms are unclear (3). Although it seems reasonable to suppose that $\mathrm{Ca}^{2+}$-stimulated $\mathrm{Cl}^{-}$secretion is mediated by CaCCs, various evidence suggests that $\mathrm{Ca}^{2+}$ stimulates $\mathrm{Cl}^{-}$secretion via CFTR.
Evidence supporting a role for $\mathrm{CaCCs}$ in $\mathrm{Ca}^{2+}$-stimulated secretion. We note 5 lines of evidence in support for this role. (a) CaCCs have been previously described in acutely isolated colonocytes (33) as well as a variety of colonic cell lines, including T84, Caco2, and HT29 (34). (b) Although knockout of CFTR abolishes cAMPinduced volume decrease of colonic crypt cells mediated by CFTR, knockout of CFTR has no effect on $\mathrm{Ca}^{2+}$-induced volume decrease mediated by $4,4^{\prime}$-diisothiocyanatostilbene-2,2'-disulfonic acid-sensitive CaCC channels (35). (c) Although knockout of CFTR abolishes $\mathrm{Ca}^{2+}$-activated $\mathrm{Cl}^{-}$currents in many mouse strains, several inbred strains of mice have been described in which $\mathrm{Ca}^{2+}$-activated $\mathrm{Cl}^{-}$secretion is present even though the 
A

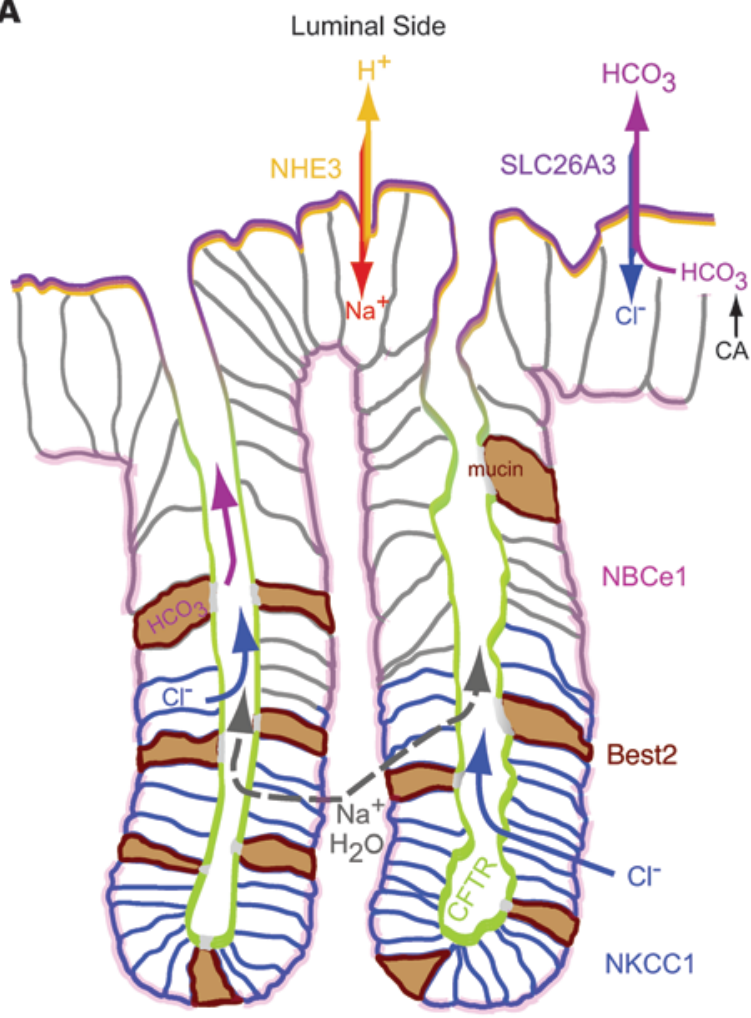

Serosal Side
B

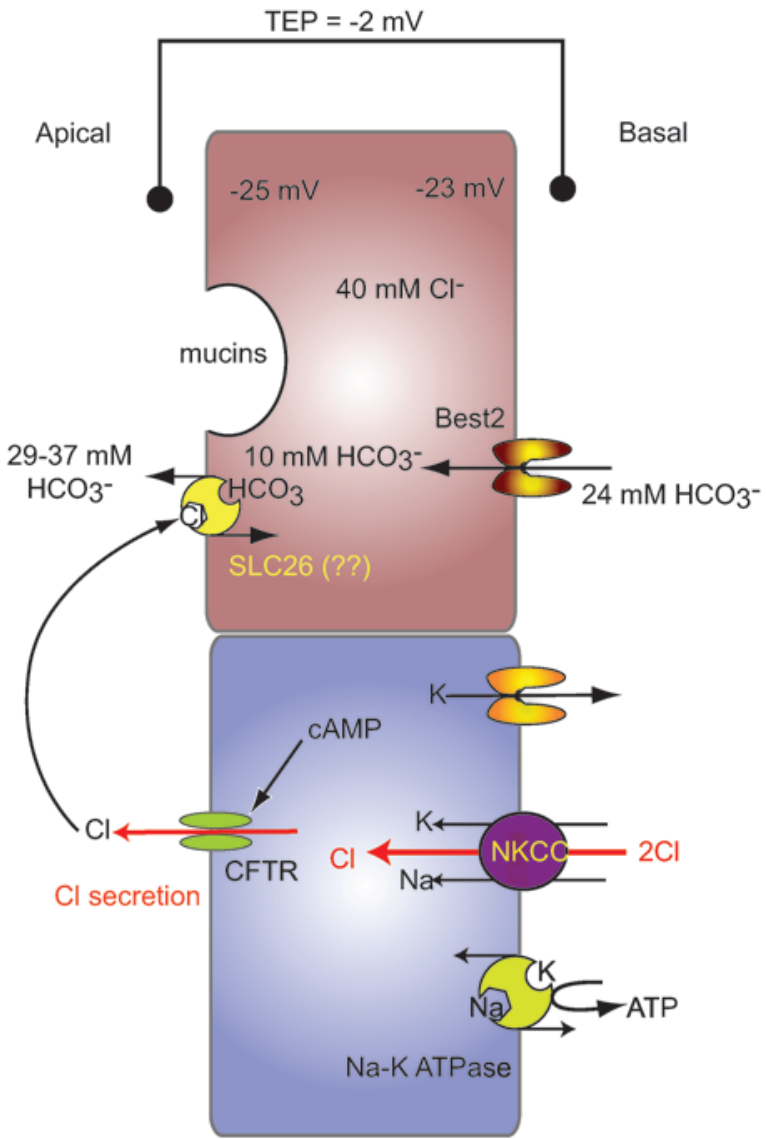

Figure 10

Ion transport in distal colon. (A) Transporters and channels in colon. The distribution of channels and transporters was determined by immunofluorescence confocal microscopy. Secretion occurs in the crypt, and absorption occurs at the luminal brush border. Secretion is driven by transepithelial $\mathrm{Cl}^{-}$transport that occurs by active basolateral uptake of $\mathrm{Cl}^{-}$by the $\mathrm{Na}^{+} / \mathrm{K}^{+} / 2 \mathrm{Cl}^{-}$cotransporter NKCC1 (blue) and subsequent passive efflux via apical CFTR $\mathrm{Cl}^{-}$channels (green). $\mathrm{Cl}^{-}$transport is accompanied - paracellularly and possibly transcellularly - by $\mathrm{H}_{2} \mathrm{O}$ and and $\mathrm{Na}^{+}$(gray). $\mathrm{Na}^{+}$and $\mathrm{Cl}^{-}$are then reabsorbed at the brush border surface by coupled $\mathrm{Na}^{+}-\mathrm{H}^{+}$exchange (by $\mathrm{NHE}^{-}$; orange) and $\mathrm{Cl}^{-}-\mathrm{HCO}_{3}{ }^{-}$ exchange (by SLC26A3; magenta) coupled to carbonic anhydrase (CA). Best2 (brown) is expressed basolaterally in goblet cells. Na+ is also reabsorbed by the $\mathrm{ENaC}$ (not shown). $\mathrm{HCO}_{3}{ }^{-}$is taken up by basolateral NBCe1 (pink), but apical mechanisms are not clear. (B) Interaction of goblet cells and enterocytes. Goblet cells (brown) are hypothesized to secrete $\mathrm{HCO}_{3}{ }^{-}$by transcellular transport involving Best2 in the basolateral membrane and $\mathrm{a} \mathrm{Cl}: \mathrm{HCO}_{3}-$ transporter in the apical membrane (see Discussion). Enterocytes (blue) secrete $\mathrm{Cl}$ - by transcellular transport involving basolateral NKCC1 and apical CFTR.

CFTR gene has been disrupted. This suggests that $\mathrm{CaCC}$ channel expression might be strain specific (36-38). (d) A subset of human cystic fibrosis patients exhibit residual colonic $\mathrm{Cl}^{-}$conductance that is likely mediated by CaCCs (39). (e) Rotavirus infection produces diarrhea by stimulating $\mathrm{Ca}^{2+}$-dependent $\mathrm{Cl}^{-}$secretion from crypts (40), and the rotavirus toxin NSP4 induces $\mathrm{Ca}^{2+}$-mediated $\mathrm{Cl}^{-}$secretion in both WT and CFTR-knockout crypts (41).

Evidence against a role for CaCCs. There are 3 lines of evidence that support the idea $\mathrm{Ca}^{2+}$ activates $\mathrm{K}_{\mathrm{Ca}} 3.1$ channels that hyperpolarize the membrane and increase the driving force for anion secretion through CFTR (10-13). (a) It has been proposed that endogenous prostaglandin production stimulates adenylyl cyclase and that CFTR is partially activated under resting conditions. This idea is supported by the observation that suppression of prostaglandin production with indomethacin blocks CCh-stimulated $\mathrm{I}_{\mathrm{sc}}(10,11)$. However, we found here that indomethacin also blocked Best2. (b) The observation that the CCh-activated $\mathrm{I}_{\mathrm{sc}}$ is potentiated by elevation of cAMP suggests a role for CFTR in $\mathrm{Ca}^{2+}$-stimulated $\mathrm{Cl}^{-}$secretion (10). How- ever, the synergistic interaction between $\mathrm{Ca}^{2+}$ and cAMP could occur at a site other than CFTR. For example, because cAMP activates Kv7.1 channels, the resulting hyperpolarization would be expected to increase the driving force for $\mathrm{Cl}^{-}$efflux through CaCCs. (c) CChactivated $\mathrm{I}_{\mathrm{sc}}$ is abolished or reduced in many mouse models of cystic fibrosis $(42,43)$ and in human biopsies from CF patients $(11,44$, 45); however, as noted above, other studies have obtained different results. The differences may be explained by changes that occur as a secondary consequence of disruption of the gene encoding CFTR. CFTR is known to regulate a variety of ion channels and transporters, including CaCCs (46), and there may simply be compensatory changes in expression of other channels, including Best2. Finally, the idea that membrane hyperpolarization is required for a cholinergic response is not universal: cholinergic agonists can stimulate anion secretion when the membrane potential is clamped at a depolarized level (6) and when $\mathrm{K}_{\mathrm{Ca}} 3.1$ channels are blocked pharmacologically (9). Although species differences may explain some discrepancies, the mechanisms of cholinergic action in colon are clearly murky. 
We suggest that the colon has 2 kinds of CaCC currents, one likely mediated by Best 2 and physiologically carried by $\mathrm{HCO}_{3}^{-}$, and another that may be mediated by an Ano1-encoded classical CaCC. $\mathrm{Ca}^{2+}$-stimulated $\mathrm{Cl}^{-}$transport is likely to involve both CaCCs and CFTR, but the ratio of these pathways may be regulated.

Mechanisms of $\mathrm{HCO}_{3}$ secretion in colon. The transport proteins involved in $\mathrm{HCO}_{3}{ }^{-}$secretion from distal colon have not been clearly delineated $(1,2)$. In other tissues, in which $\mathrm{HCO}_{3}{ }^{-}$secretion has been studied more thoroughly (29), $\mathrm{HCO}_{3}^{-}$transport is mediated by coordinated basolateral $\mathrm{Na}: \mathrm{HCO}_{3}{ }^{-}$transporters and apical $\mathrm{Cl}: \mathrm{HCO}_{3}$ exchangers. In the colon, the role of $\mathrm{Na}: \mathrm{HCO}_{3}{ }^{-}$transporters is controversial (47, 48), and at least 3 different apical $\mathrm{HCO}_{3}{ }^{-}$efflux mechanisms have been identified (49). It remains unclear exactly which cells secrete $\mathrm{HCO}_{3}{ }^{-}$and how much of the $\mathrm{HCO}_{3}{ }^{-}$secretion occurs at the brush border and in the crypt. SLC26A3 is one of the $\mathrm{Cl}: \mathrm{HCO}_{3}$ exchangers in the apical membrane that mediates $\mathrm{HCO}_{3}{ }^{-}$secretion $(50,51)$. It has been proposed that CFTR-mediated $\mathrm{HCO}_{3}{ }^{-}$secretion is explained by direct effects of CFTR on SLC26A3 (52), but in the colon, SLC26A3 is located on the brush border membrane, whereas CFTR is expressed in the crypts (ref. 50 and H.C. Hartzell, unpublished observations). Thus, it seems unlikely that CFTR-mediated $\mathrm{HCO}_{3}{ }^{-}$secretion occurs by direct regulation of SLC26A3 in the colon. Another possibility is that CFTR stimulates $\mathrm{HCO}_{3}{ }^{-}$secretion indirectly by elevating extracellular $\mathrm{Cl}^{-}$and thereby driving $\mathrm{Cl}-\mathrm{HCO}_{3}$ exchange in adjacent goblet cells.

Best 2 is a colonic anion channel. A considerable body of evidence has established that bestrophins are a type of $\mathrm{Ca}^{2+}$-activated $\mathrm{Cl}^{-}$channel (14). However, we showed here that Best2 did not function as a classical $\mathrm{Ca}^{2+}$-activated $\mathrm{Cl}^{-}$channel, as was initially anticipated. Best 1 is expressed on the brush border membrane of colonocytes in proximal colon and has been suggested to participate in $\mathrm{Cl}^{-}$ secretion $(7,8)$, but it remains to be seen whether Best 2 and Best 1 differ in their localization and function.

Our findings here complement a growing realization that bestrophins are unlikely to be the Xenopus oocyte variety of $\mathrm{Ca}^{2+}$ activated $\mathrm{Cl}^{-}$channels (CaCCs), such as the ones present in salivary gland and pancreatic acinar cells $(14,17,53)$. Differences between bestrophins and CaCCs include differences in their $\mathrm{Ca}^{2+}$ sensitivity, voltage dependence and kinetics, methods of regulation, and bicarbonate permeability (54). The first definitive evidence that bestrophins were not classical CaCCs was the finding that knockout of BEST1 in mice did not eliminate CaCC currents in retinal pigment epithelial cells in which Best 1 is expressed $(17,55)$. These studies have led to the suggestion that bestrophins, in addition to functioning as $\mathrm{Cl}^{-}$channels, may also have other regulatory functions, including regulation of voltage-gated $\mathrm{Ca}^{2+}$ channels (14).

Speculation regarding disorders of ion transport in inflammatory bowel disease. Ion transport is disrupted in many inflammatory diseases in airway, kidney, and gastrointestinal tract $(2,56-58)$. It is tantalizing that the Best2 gene is located within a susceptibility locus for inflammatory bowel disease (i.e., IBD6; refs. 59-61). Our observations that Best $2^{-/-}$mice exhibited enhanced inflammation, slow recovery from DSS-induced colitis, and altered mucin biogenesis raise the possibility that Best 2 may play a role in inflammatory bowel diseases.

\section{Methods}

Mice. Generation of Best $2^{-/-}$mice has previously been described (18). In initial experiments, control mice were C57BL/6 mice, but later experiments used control mice bred with the same genetic background as that of Best $2^{-/-}$mice; results were the same. All animals were bred and maintained in accordance with NIH and institutional guidelines, and all procedures were approved by the Emory University Institutional Animal Care and Use Committee. Agematched mice of either gender were randomly assigned to the experimental procedures. Animals were sacrificed by isoflurane inhalation anesthesia or $\mathrm{CO}_{2}$ asphyxiation until breathing ceased, followed by decapitation.

Human tissue. Use of human tissue was approved by the Emory University Institutional Review Board as exempt from IRB review because the study does not meet Federal Regulations 45 CFR Section 46.102(f)(2) criteria for "research involving human subjects." Tissue samples were deidentified and impossible for us to trace back to the patient's identity.

Immunofluorescence. Colon tissue was fixed in $4 \%$ paraformaldehyde buffered with $0.1 \mathrm{M}$ phosphate buffer ( $\mathrm{pH} 7.4$ ), frozen, and embedded in OCT compound. Sections were treated with $0.025 \%$ saponin in PBS at room temperature for 30 minutes, then rinsed in PBS and blocked with $3 \%$ BSA (or $1 \%$ cold water fish gelatin) and normal goat serum for 1 hour at room temperature. Sections were incubated with primary antibodies (diluted 1:500-1:1,000) overnight at $4^{\circ} \mathrm{C}$ in a humidified chamber. Antibodies included anti-Best 2 (provided by A. Menini, Italian Institute of Technology, Trieste, Italy; or our own antibody raised to amino acids 386-485), anti-MUC2, anti-CFTR (3G11, provided by Cystic Fibrosis Foundation; or provided by N. Nameen, University of Pittsburgh), and anti-Ano1 (raised against amino acids 878-960). Ano1 cDNA was provided by U. Oh (Seoul National University, Seoul, South Korea). After washing 5 times with PBS, we incubated the sections with Alexa dye-conjugated (Invitrogen) or Daylite dye-conjugated (Jackson Immunochemicals) goat anti-rabbit secondary antibody for 2-4 hours at room temperature. The sections were washed again in PBS, mounted in Prolong Gold (Invitrogen), and examined using a Zeiss LSM-510 microscope. The anti-Best 2 antibody stained HEK cells transfected with Best2, but not untransfected cells or cells transfected with mouse Best 1 or Best3. The antibody did not stain tissue from Best $2^{-/-}$mice.

Western blot analysis. Colons were flushed with PBS, after which the mucosa was scraped off a distal piece $(0.5 \mathrm{~cm})$ with a razor blade and homogenized in lysis buffer containing 1\% Triton X-100, 1 mM EDTA, $50 \mathrm{mM}$ Tris-HCl ( $\mathrm{pH}$ 7.4), and protease inhibitor cocktail III (Calbiochem) plus $10 \mu \mathrm{M}$ phenylmethylsulfonyl chloride. Protein content was determined by BCA assay (Pierce), the samples were diluted in SDS Laemmli buffer, and aliquots were run on $7 \%-12 \%$ reducing SDS-PAGE, transferred to nitrocellulose, and detected with anti-Best 2 or Ano1 antibody.

Using chamber experiments. We used $2 \mathrm{~cm}$ of the mouse distal colon. Muscle layers were removed by gentle dissection, and a piece of mucosa was mounted in an Ussing chamber (Physiologic Instruments Inc.) with an aperture of $0.3 \mathrm{~cm}^{2}$ (or, in some experiments, $0.07 \mathrm{~cm}^{2}$ ). The standard Krebs-Henseleit solution contained $118 \mathrm{mM} \mathrm{NaCl}, 4.7 \mathrm{mM} \mathrm{KCl}, 23 \mathrm{mM}$ $\mathrm{NaHCO}_{3}, 1.2 \mathrm{mM} \mathrm{K}_{2} \mathrm{HPO}_{4}, 1.2 \mathrm{mM} \mathrm{CaCl}_{2}, 1.2 \mathrm{mM} \mathrm{MgCl}$, $0.3 \mathrm{mM}$ EDTA, and $10 \mathrm{mM}$ glucose. The reservoirs were vigorously gassed with $5 \% \mathrm{CO}_{2}$ and $95 \% \mathrm{O}_{2}$ and maintained at $37^{\circ} \mathrm{C}$ by water jackets. $\mathrm{I}_{\mathrm{sc}}$ was measured using an automatic voltage clamping device (DVC-1000; Physiologic Instruments Inc.) that compensates for resistance of the solution between the potential measuring electrodes. TEP was recorded through $3 \mathrm{M} \mathrm{KCl}$-agar bridges connected to a pair of calomel half-cells. The transepithelial current was applied across the tissue via a pair of $\mathrm{Ag} / \mathrm{AgCl}$ electrodes that were kept in contact with the mucosal and serosal bathing solution using $3 \mathrm{M} \mathrm{KCl}$-agar bridges. All experiments were done under short-circuit conditions. The $\mathrm{I}_{\mathrm{sc}}$ is negative when positive current flows from serosa to mucosa. The tissue was placed in the apparatus and equilibrated for 30-40 minutes to stabilize $\mathrm{I}_{\mathrm{sc}}$ before starting the experiment. The baseline value of electrical parameters was determined as the mean over the 2 minutes immediately prior to drug administration. A positive $\mathrm{I}_{\mathrm{sc}}$ corresponds to the net electrogenic secretion of anions or the net electrogenic absorption of cations. Carbamylcholine (CCh, $1 \mathrm{mM})$ and forskolin $(10 \mu \mathrm{M})$ were used to activate the ion transport. 
To reduce the contribution of cation currents to the $\mathrm{I}_{\mathrm{sc}}$, the $\mathrm{K}^{+}$channel blocker $\mathrm{Ba}^{2+}(5 \mathrm{mM})$ and the epithelial $\mathrm{Na}^{+}$channel blocker amiloride $(100 \mu \mathrm{M})$ were added at the start of most experiments.

Isolation of colonic epithelial cells. A 4-cm piece of mouse distal colon was everted and rinsed with ice-cold $\mathrm{Ca}^{2+}$-free Ringer's-type solution composed of $127 \mathrm{mM}$ $\mathrm{NaCl}, 5 \mathrm{mM} \mathrm{KCl}, 5 \mathrm{mM}$ Na-pyruvate, $5 \mathrm{mM}$ glucose, $10 \mathrm{mM}$ HEPES, $27 \mathrm{mM}$ EDTA, and $1 \mathrm{mM} \mathrm{MgCl}_{2}$. This preparation was then incubated in normal Krebs solution for 10 minutes at $37^{\circ} \mathrm{C}$. Isolated crypts were obtained by shaking and then treated with collagenase-P (20 U/ml; Roche Applied Science) for 10 minutes. Isolated colonocytes from crypts were collected and replated in DMEM (Invitrogen) supplemented with 10\% fetal bovine serum and penicillinstreptomycin $(200 \mu \mathrm{g} / \mathrm{ml}$ and $200 \mathrm{U} / \mathrm{ml}$, respectively). Studies were performed within 24 hours of the acute isolation.

$X$-gal staining of tissue. Distal colon $(2 \mathrm{~cm})$ was removed, opened lengthwise by a longitudinal incision, and pinned in a Sylgard-coated $35-\mathrm{mm}$ dish. The tissue was fixed in $4 \%$ paraformaldehyde in $0.1 \mathrm{M}$ phosphate buffer $(\mathrm{pH} 7.4)$ for 1 hour; rinsed 3 times with rinse buffer containing $0.1 \mathrm{M}$ sodium phosphate buffer, $2 \mathrm{mM} \mathrm{MgCl}_{2}, 0.01 \%$ sodium deoxycholate, and $0.02 \% \mathrm{NP}-40$; and incubated overnight in $20 \mathrm{mM}$ potassium ferrocyanide, $20 \mathrm{mM}$ potassium ferricyanide, and $1 \mathrm{mg} / \mathrm{ml}$ solution of $\mathrm{X}$-gal in PBS. Tissue was examined with a microscope and photographed with a color CCD camera.

Immunoelectron microscopy. Immunoelectron microscopy was performed as described previously, using a preembedding immunogold method (62). Colons were fixed by immersion with $4 \%$ paraformaldehyde and $0.1 \%$ glutaraldehyde in $0.1 \mathrm{M}$ phosphate buffer, after which $60-\mu \mathrm{m}$ sections were cut on a Vibratome (VT1000S; Leica) and blocked in Tris-buffered saline (TBS) containing $10 \%$ normal goat serum (NGS) for 1 hour. Sections were then incubated for 48 hours in anti-Best 2 antibodies in TBS containing $10 \%$ NGS. After several washes in TBS, sections were incubated for 2 hours in goat antirabbit IgG coupled to $1.4 \mathrm{~nm}$ gold (Nanoprobes Inc.) diluted 1:100 in TBS containing $1 \%$ NGS. Sections were washed in PBS, and the sections were postfixed in $1 \%$ glutaraldehyde diluted in the same buffer for 10 minutes. They were washed in double-distilled $\mathrm{H}_{2} \mathrm{O}$, followed by silver enhancement of the gold particles with an HQ Silver kit (Nanoprobes Inc.). Sections were then treated with $1 \%$ osmium tetroxide in $0.1 \mathrm{M}$ phosphate buffer, block-stained with uranyl acetate, dehydrated in graded series of ethanol, and flat-embedded on glass slides in Durcupan (Fluka) resin. Regions of interest were cut at $70-90 \mathrm{~nm}$ on an ultramicrotome (Reichert Ultracut E; Leica) and collected on 200-mesh nickel grids. Staining was performed on drops of $1 \%$ aqueous uranyl acetate followed by Reynolds's lead citrate. Ultrastructural analyses were performed in a Jeol-1010 electron microscope. To test specificity, the primary antibody was either omitted or replaced with $5 \%(\mathrm{v} / \mathrm{v})$ normal rabbit serum. Under these conditions, no selective labeling was observed.

Patch clamp recording. Acutely isolated single colonocytes were recorded using conventional patch-clamp techniques. Fire-polished borosilicate glass patch pipettes were 3-5 M $\Omega$. Experiments were conducted at room temperature $\left(20^{\circ} \mathrm{C}-24^{\circ} \mathrm{C}\right)$. Because the liquid junction potentials were small (less than $2 \mathrm{mV}$ ), no correction was made. The standard pipette solution contained $146 \mathrm{mM} \mathrm{CsCl}, 2 \mathrm{mM} \mathrm{MgCl} 2,5 \mathrm{mM}\left(\mathrm{Ca}^{2+}\right)$-EGTA, $10 \mathrm{mM}$ HEPES, and $10 \mathrm{mM}$ sucrose ( $\mathrm{pH}$ 7.3), adjusted with $\mathrm{N}$-methyl-Dglucamine. The calculated $\mathrm{Ca}^{2+}$ concentrations were approximately $1 \mu \mathrm{M}$ in high- $\mathrm{Ca}^{2+}$ solution. The standard extracellular solution contained $140 \mathrm{mM}$ $\mathrm{NaCl}, 5 \mathrm{mM} \mathrm{KCl}, 2 \mathrm{mM} \mathrm{CaCl}, 1 \mathrm{mM} \mathrm{MgCl} 2,15 \mathrm{mM}$ glucose, and $10 \mathrm{mM}$
HEPES ( $\mathrm{pH}$ 7.4) with $\mathrm{NaOH}$. This combination of intracellular and extracellular solutions set reversal potential $\left(\mathrm{E}_{\text {rev }}\right)$ for $\mathrm{Cl}^{-}$currents to 0 , whereas cation currents carried by $\mathrm{Na}^{+}$or $\mathrm{Cs}^{+}$had very positive or negative $\mathrm{E}_{\text {rev }}$, respectively. In $\mathrm{HCO}_{3}{ }^{-}$-containing solution, $140 \mathrm{mM} \mathrm{NaHCO}$ replaced $\mathrm{NaCl}$ on an equimolar basis, and the solution was equilibrated with $30 \% \mathrm{CO}_{2}$ and $70 \% \mathrm{O}_{2}$. Osmolarity was adjusted with sucrose to $303 \mathrm{mOsM}$ for all solutions. Relative permeability was determined from the Goldman-Hodgkin-Katz equation, as previously described (21). Relative conductance was calculated from the slope of the current-voltage relationship $\pm 25 \mathrm{mV}$ of the reversal potential.

Induction of DSS colitis. Sex- and age-matched littermates, approximately 3 months old, received 3\% DSS (MP Biomedicals) in drinking water for 6 days followed with normal water for recovery. Weight was recorded daily.

MPO activity. Neutrophil infiltration was quantified by measuring MPO activity. Colon samples were homogenized in 1:20 (w/v) of $50 \mathrm{mM}$ phosphate buffer ( $\mathrm{pH} 6.0$ ) containing $0.5 \%$ hexadecyltrimethyl ammonium bromide (Sigma-Aldrich), on ice using a Polytron homogenizer. The homogenate was sonicated for 10 seconds, freeze-thawed 3 times, and centrifuged at $21,000 \mathrm{~g}$ for 15 minutes. The supernate $(14 \mu \mathrm{l})$ was added to $1 \mathrm{mg} / \mathrm{ml} o$-dianisidine hydrochloride (Sigma-Aldrich) and $0.0005 \%$ hydrogen peroxide (Sigma-Aldrich), and the change in absorbance at $460 \mathrm{~nm}$ over time was measured. One unit of MPO activity was defined as the amount that degraded $1 \mu \mathrm{mol}$ peroxidase per minute at $25^{\circ} \mathrm{C}$. Results are expressed as MPO units per microgram protein, determined by BioRad protein assay.

Statistics. Data are expressed as mean \pm SEM. Statistical difference between means was evaluated by 2 -tailed Student's $t$ test. The body weight difference between WT and Best $2^{-/-}$mice was evaluated by factorial ANOVA of age (14 time points) and phenotype. Statistical significance was assumed for $P$ values less than 0.05 .

\section{Acknowledgments}

The authors thank Didier Merlin for the use of his Ussing Chamber setup and helpful discussion, Asma Nusrat for advice on histological and pathological analysis, Qinghuan Xiao for comments on the manuscript, Anna Menini for Best2 antibody, the Cystic Fibrosis Foundation for CFTR (3G11) antibody, Nadia Nameen for CFTR antibody, and Uhtaek Oh for Ano1 cDNA. The authors' work is supported by NIH grants GM60448 (to H.C. Hartzell), EY014852 (to H.C. Hartzell), and EY13160 (to A. Marmorstein); by an American Health Assistance Foundation grant (to A. Marmorstein); by an unrestricted grant to the Department of Ophthalmology and Vision Science at the University of Arizona (to A. Marmorstein); and by Emory University Core Grant for Vision Research P30 EY006360 (to H.C. Hartzell).

Received for publication September 10, 2009, and accepted in revised form February 17, 2010.

Address correspondence to: H. Criss Hartzell, Department of Cell Biology, Emory University School of Medicine, 615 Michael St., 535 Whitehead Building, Atlanta, Georgia 30322, USA. Phone: 404.242.5719; Fax: 404.727.6256; E-mail: Criss. Hartzell@emory.edu.
1. Heitzmann D, Warth R. Physiology and pathophysiology of potassium channels in gastrointestinal epithelia. Physiol Rev. 2008;88(3):1119-1182.

2. Kunzelmann K, Mall M. Electrolyte transport in the mammalian colon: mechanisms and implications for disease. Physiol Rev. 2002;82(1):245-289.

3. Barrett KE, Keely SJ. Chloride secretion by the intestinal epithelium: molecular basis and regula- tory aspects. Annu Rev Physiol. 2000;62:535-572. 4. Musch MW, Arvans DL, Wu GD, Chang EB. Functional coupling of the downregulated in adenoma $\mathrm{Cl}-$ /base exchanger DRA and the apical $\mathrm{Na}+/ \mathrm{H}+$ exchangers NHE2 and NHE3. Am J Physiol Gastrointest Liver Physiol. 2009;296(2):G202-G210.

5. Greger R. Role of CFTR in the colon. Annu Rev Physiol. 2000;62:467-491.
6. Hennig B, Schultheiss G, Kunzelmann K, Diener $\mathrm{M}$. Ca2+-induced Cl- efflux at rat distal colonic epithelium. J Membr Biol. 2008;221(2):61-72.

7. Kunzelmann K, Milenkovic VM, Spitzner M, Soria RB, Schreiber R. Calcium-dependent chloride conductance in epithelia: is there a contribution by Bestrophin? Pflugers Arch. 2007;454(6):879-889.

8. Barro Soria R, Spitzner M, Schreiber R, Kun- 
zelmann K. Bestrophin 1 enables $\mathrm{Ca}^{2+}$ activated $\mathrm{Cl}^{-}$conductance in epithelia. J Biol Chem. 2009; 284(43):29405-29412.

9. Halm ST, Liao T, Halm DR. Distinct $\mathrm{K}+$ conductive pathways are required for $\mathrm{Cl}-$ and $\mathrm{K}+$ secretion across distal colonic epithelium. Am J Physiol Cell Physiol. 2006;291(4): C636-C648.

10. Mall M, et al. Cholinergic ion secretion in human colon requires coactivation by cAMP. Am J Physiol. 1998;275(6 Pt 1):G1274-G1281.

11. Mall M, et al. Defective cholinergic $\mathrm{Cl}(-)$ secretion and detection of $\mathrm{K}(+)$ secretion in rectal biopsies from cystic fibrosis patients. Am J Physiol Gastroin test Liver Physiol. 2000;278(4):G617-G624.

12. Flores CA, Melvin JE, Figueroa CD, Sepulveda FV. Abolition of $\mathrm{Ca} 2+$-mediated intestinal anion secretion and increased stool dehydration in mice lacking the intermediate conductance $\mathrm{Ca} 2+$-dependent $\mathrm{K}+$ channel Kcnn4. J Physiol. 2007;583(Pt 2):705-717.

13. Matos JE, Sausbier M, Beranek G, Sausbier U, Ruth $\mathrm{P}$, Leipziger J. Role of cholinergic-activated KCa1.1 (BK), KCa3.1 (SK4) and KV7.1 (KCNQ1) channels in mouse colonic Cl- secretion. Acta Physiol (Oxf). 2007; 189(3):251-258.

14. Hartzell HC, Qu Z, Yu K, Xiao Q, Chien LT. Molecular Physiology of Bestrophins: Multifunctional membrane proteins linked to Best Disease and other retinopathies. Physiol Rev. 2008;88(2):639-672.

15. Hartzell HC, Yu K, Xiao Q, Chien LT, Qu Z. Anoctamin/TMEM16 family members are $\mathrm{Ca}^{2+}$-activated $\mathrm{Cl}^{-}$channels. J Physiol. 2009;587(Pt. 10):2127-2139.

16. Duran C, Thompson CH, Xiao Q, Hartzell HC. Chloride Channels: Often enigmatic, rarely predictable. Annu Rev Physiol. 2010;72:95-121.

17. Marmorstein AD, Cross HE, Peachey NS. Functional roles of bestrophins in ocular epithelia. Prog Retin Eye Res. 2009;28(1):206-226.

18. Bakall B, et al. Bestrophin-2 is involved in the generation of intraocular pressure. Invest Ophthalmol Vis Sci. 2008;49(4):1563-1570.

19. Specian RD, Neutra MR. Mechanism of rapid mucus secretion in goblet cells stimulated by acetylcholine. J Cell Biol. 1980;85(3):626-640.

20. Specian RD, Oliver MG. Functional biology of intestinal goblet cells. Am J Physiol. 1991; 260(2 Pt 1):C183-C193.

21. Qu Z, Hartzell HC. Bestrophin Cl- channels are highly permeable to $\mathrm{HCO} 3$. Am J Physiol Cell Physiol. 2008;294(6):C1371-C1377.

22. Caputo A, et al. TMEM16A, a membrane protein associated with calcium-dependent chloride channel activity. Science. 2008;322(5901):590-594

23. Schroeder BC, Cheng T, Jan YN, Jan LY. Expression cloning of TMEM16A as a calcium-activated chloride channel subunit. Cell. 2008;134(6):1019-1029.

24. Yang YD, et al. TMEM16A confers receptor-activated calcium-dependent chloride conductance. Nature. 2008;455(7217):1210-1215.

25. Gomez-Pinilla PJ, et al. Ano1 is a selective marker of interstitial cells of Cajal in the human and mouse gastrointestinal tract. Am J Physiol Gastrointest Liver Physiol. 2009;296(6):G1370-G1381.

26. Okayasu I, Hatakeyama S, Yamada M, Ohkusa T, Inagaki Y, Nakaya R. A novel method in the induction of reliable experimental acute and chronic ulcerative colitis in mice. Gastroenterology. 1990; 98(3):694-702.

27. Barro-Soria R, Aldehni F, Almaca J, Witzgall R, Schreiber R, Kunzelmann K. ER-localized bestrophin 1 activates $\mathrm{Ca}(2+)$-dependent ion channels TMEM16A and SK4 possibly by acting as a counterion channel. Pflugers Arch. 2010;459(3):485-497.

28. Dagher PC, Chawla H, Michael J, Egnor RW, Charney AN. Modulation of chloride secretion in the rat ileum by intracellular bicarbonate. Comp Biochem Physiol A Physiol. 1997;117(1):89-97.

29. Steward MC, Ishiguro H, Case RM. Mechanisms of bicarbonate secretion in the pancreatic duct. Annu Rev Physiol. 2005;67:377-409.

30. Perez-Vilar J. Mucin granule intraluminal organization. Am J Respir Cell Mol Biol. 2007;36(2):183-190.

31. Verdugo P, Deyrup-Olsen I, Aitken M, Villalon M, Johnson D. Molecular mechanism of mucin secretion: I. The role of intragranular charge shielding. J Dent Res. 1987;66(2):506-508.

32. Garcia MA, Yang N, Quinton PM. Normal mouse intestinal mucus release requires cystic fibrosis transmembrane regulator-dependent bicarbonate secretion. J Clin Invest. 2009;119(9):2613-2622.

33. Sahi J, Wiggins MP, Gibori GB, Layden TJ, Rao MC. Calcium regulated chloride permeabilities in primary cultures of rabbit colonocytes. J Cell Physiol. 1996;168(2):276-283

34. Arreola J, Melvin JE, Begenisich T. Differences in regulation of $\mathrm{Ca} 2+$-activated $\mathrm{Cl}$ - channels in colonic and parotid secretory cells. Am J Physiol. 1998;274(1 Pt 1):C161-C166.

35. Valverde MA, O'Brien JA, Sepulveda FV, Ratcliff $\mathrm{R}$, Evans MJ, Colledge WH. Inactivation of the murine cftr gene abolishes cAMP-mediated but not $\mathrm{Ca}(2+)$-mediated secretagogue-induced volume decrease in small-intestinal crypts. Pflugers Arch. 1993;425(5-6):434-438.

36 . Toth B, et al. Very mild disease phenotype of congenic CftrTgH(neoim)Hgu cystic fibrosis mice. BMC Genet. 2008;9:28.

37. Rozmahel R, et al. Modulation of disease severity in cystic fibrosis transmembrane conductance regulator deficient mice by a secondary genetic factor. Nature Genetics. 1996;12(3):280-287.

38. Flores CA, Cid LP, Sepulveda FV. Strain-dependent differences in electrogenic secretion of electrolytes across mouse colon epithelium [published online ahead of print February 12, 2010]. Exp Physiol. doi:10.1113/expphysiol.2009.051102.

39. Veeze HJ, Halley DJ, Bijman J, de Jongste JC, de Jonge HR, Sinaasappel M. Determinants of mild clinical symptoms in cystic fibrosis patients. Residual chloride secretion measured in rectal biopsies in relation to the genotype. J Clin Invest. 1994; 93(2):461-466.

40. Lorrot M, Vasseur M. How do the rotavirus NSP4 and bacterial enterotoxins lead differently to diarrhea? Virol J. 2007;4:31.

41. Morris AP, Scott JK, Ball JM, Zeng CQ, O’Neal WK, Estes MK. NSP4 elicits age-dependent diarrhea and $\mathrm{Ca}(2+)$ mediated I(-) influx into intestinal crypts of CF mice. Am J Physiol. 1999;277(2 Pt 1):G431-G444.

42. Cuthbert AW, MacVinish LJ, Hickman ME, Ratcliff R, Colledge WH, Evans MJ. Ion-transporting activity in the murine colonic epithelium of normal animals and animals with cystic fibrosis. Pflugers Arch. 1994;428(5-6):508-515

43. Bleich EM, Leonhard-Marek S, Beyerbach M, Breves G. Characterisation of chloride currents across the proximal colon in $\mathrm{Cftr} T \mathrm{TgH}($ neoim) $1 \mathrm{Hgu}$ congenic mice. J Comp Physiol B. 2007;177(1):61-73.

44. Hardcastle J, Hardcastle PT, Taylor CJ, Goldhill $\mathrm{J}$. Failure of cholinergic stimulation to induce a secretory response from the rectal mucosa in cystic fibrosis. Gut. 1991;32(9):1035-1039.

45. Berschneider HM, et al. Altered intestinal chlo- ride transport in cystic fibrosis. FASEB Journal. 1988;2(10):2625-2629.

46. Kunzelmann K, et al. The cystic fibrosis transmembrane conductance regulator attenuates the endogenous Ca2+ activated Cl- conductance of Xenopus oocytes. Pflugers Arch. 1997;435(1):178-181.

47. Gawenis LR, et al. Colonic anion secretory defects and metabolic acidosis in mice lacking the NBC1 Na+/HCO3- cotransporter. J Biol Chem. 2007;282(12):9042-9052.

48. Seidler U, Bachmann O, Jacob P, Christiani S, Blumenstein I, Rossmann H. Na+/HCO3- cotransport in normal and cystic fibrosis intestine. JOP. 2001;2(4 Suppl):247-256.

49. Binder HJ, Rajendran V, Sadasivan V, Geibel JP. Bicarbonate secretion: a neglected aspect of colonic ion transport. J Clin Gastroenterol. 2005; 39(4 Suppl 2):S53-S58.

50. Schweinfest CW, et al. slc26a3 (dra)-deficient mice display chloride-losing diarrhea, enhanced colonic proliferation, and distinct up-regulation of ion transporters in the colon.J Biol Chem. 2006;281(49):37962-37971.

51. Walker NM, et al. Role of down-regulated in adenoma anion exchanger in $\mathrm{HCO} 3$ - secretion across murine duodenum. Gastroenterology. 2009; 136(3):893-901.

52. Shcheynikov N, et al. The Slc26a4 transporter functions as an electroneutral Cl-/I. J Physiol. 2008; 586(16):3813-3824.

53. Romanenko VG, et al. Tmem 16 A encodes the Ca2+activated Cl- channel in mouse submandibular salivary gland acinar cells [published online ahead of print February 22, 2010]. J Biol Chem. doi:10.1074/ jbc.M109.068544.

54. Hartzell HC. CaCl-ing channels get the last laugh. Science. 2008;322(5901):534-535.

55 . Marmorstein LY, et al. The light peak of the electroretinogram is dependent on voltage-gated calcium channels and antagonized by bestrophin (Best-1). J Gen Physiol. 2006;127(5):577-589.

56 . Eisenhut M. Changes in ion transport in inflammatory disease. J Inflamm (Lond). 2006;3:5.

57. Sullivan S, et al. Downregulation of sodium transporters and NHERF proteins in IBD patients and mouse colitis models: Potential contributors to IBD-associated diarrhea. Inflamm Bowel Dis. 2008; 15(2):261-274.

58. Hirota CL, McKay DM. Loss of Ca-mediated ion transport during colitis correlates with reduced ion transport responses to a Ca-activated $\mathrm{K}$ channel opener. Br J Pharmacol. 2009;156(7):1085-1097.

59. Rioux JD, et al. Genomewide search in Canadian families with inflammatory bowel disease reveals two novel susceptibility loci. Am J Hum Genet. 2000;66(6):1863-1870.

60. Williams CN, Kocher K, Lander ES, Daly MJ, Rioux JD. Using a genome-wide scan and metaanalysis to identify a novel IBD locus and confirm previously identified IBD loci. Inflamm Bowel Dis. 2002;8(6):375-381.

61. van Heel DA, Fisher SA, Kirby A, Daly MJ, Rioux JD, Lewis CM. Inflammatory bowel disease susceptibility loci defined by genome scan meta-analysis of 1952 affected relative pairs. Hum Mol Genet. 2004;13(7):763-770.

62. Lujan R, Nusser Z, Roberts JD, Shigemoto R, Somogyi P. Perisynaptic location of metabotropic glutamate receptors mGluR1 and mGluR5 on dendrites and dendritic spines in the rat hippocampus. Eur J Neurosci. 1996;8(7):1488-1500. 